\title{
Prerequisite to Design a Health Promotion Intervention with a Social Marketing Approach to Reduce Fast Food Consumption among Students: A Formative Research with Mixed-Methods Approach
}

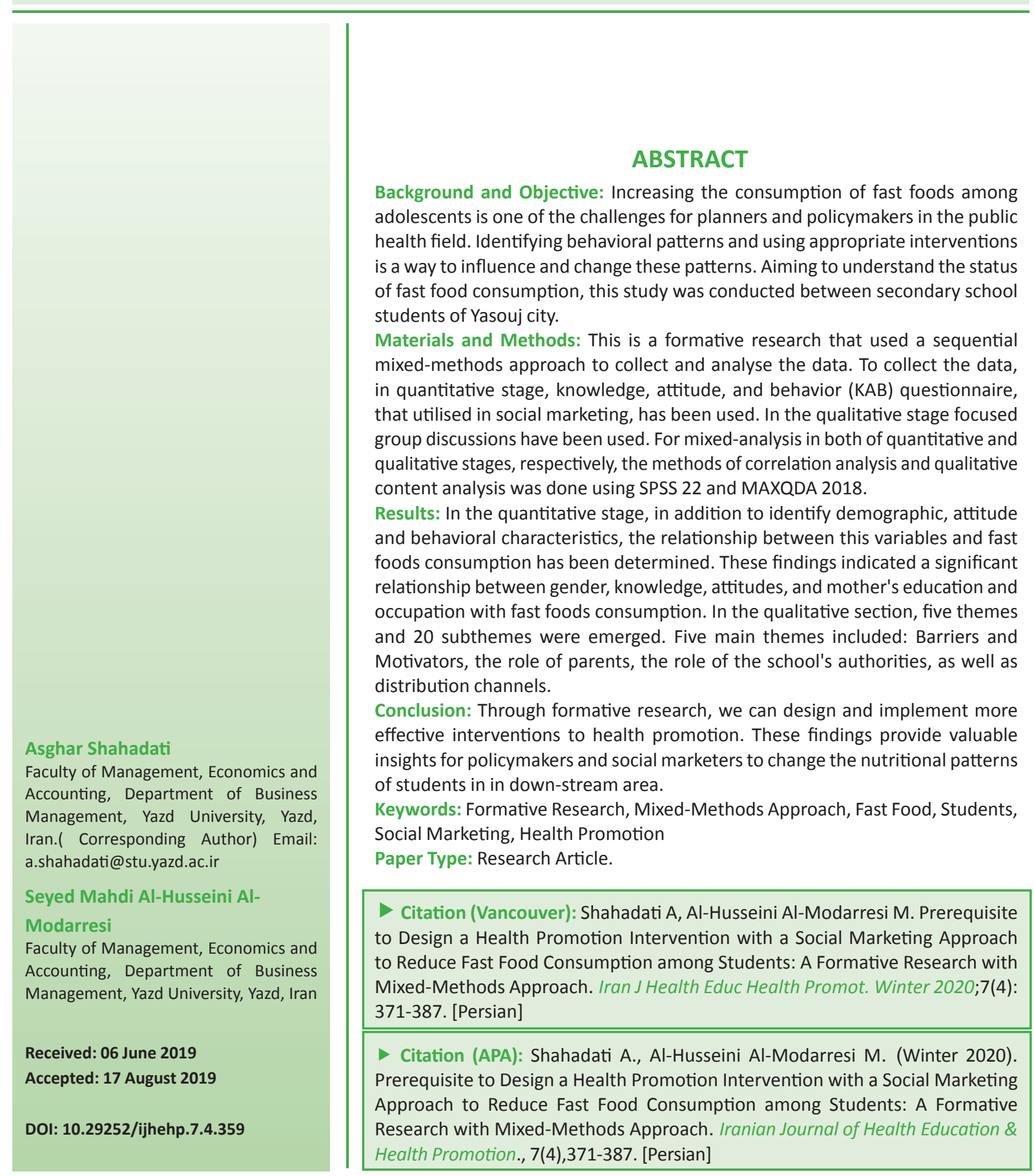




\section{بيش نياز طراحى مداخله ارتقاى سلامت با رويكرد بازاريابى اجتماعى براى كاهش مصرف غذاهاى آماده در بين دانش آموزان: يك بيروهش تكوينى با رويكرد تركيبى باريى}

\section{بك آنيله}

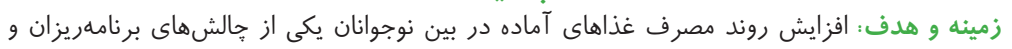

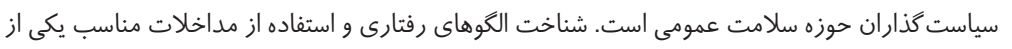

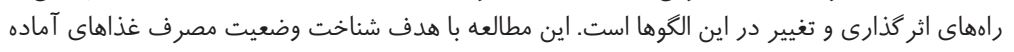

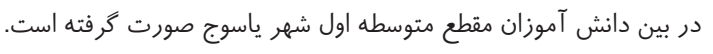

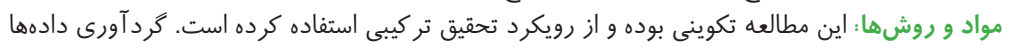

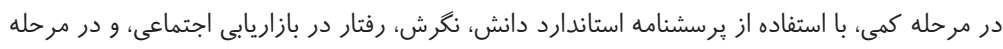

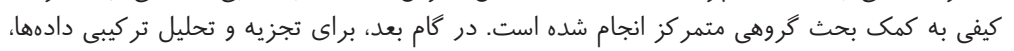

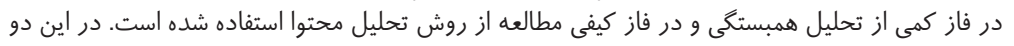

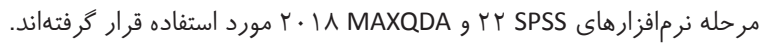

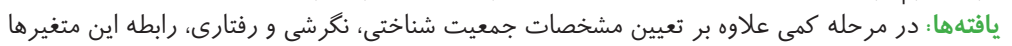

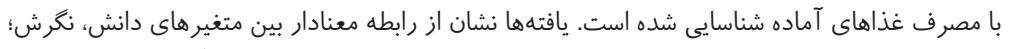

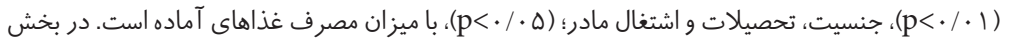

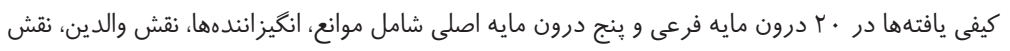

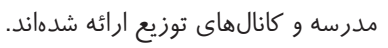

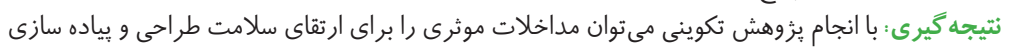

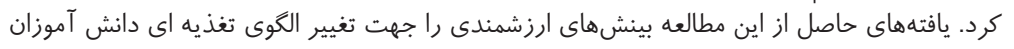

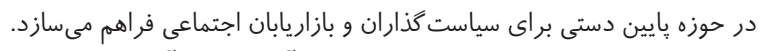

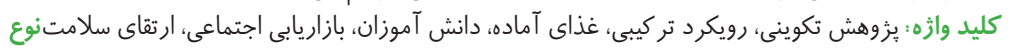

مقاله : مطالعه يزوهشى.

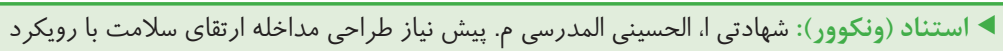

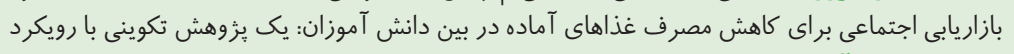

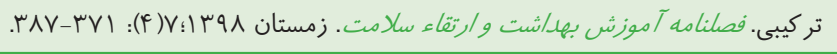

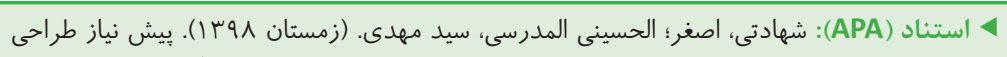

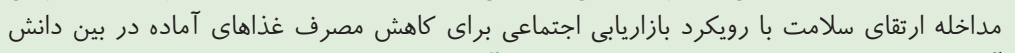

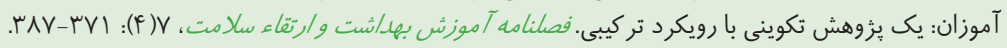

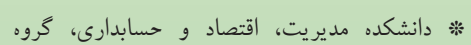

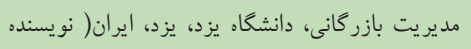
a.shahadati@stu.yazd.ac.ir

مسئول): سيد مهدى الحسينى المدرسى

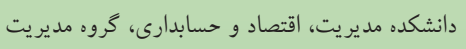
بازركانى، دانشكاه يزد، يزد، ايران انتصاد و حسابداري

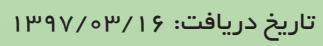
تاريخ يذيرش: 
بودريار (Baudrillard) معتقد است فرهنگ مصرف مى تواند در

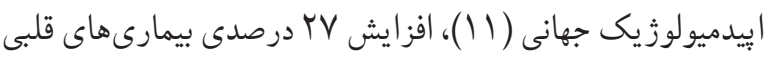
عروقى، افزايش هه درصدى بيمارى هاى قلبى ناشى از فشار خون

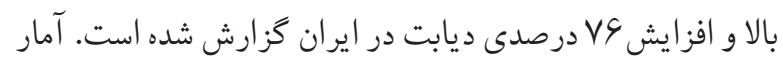

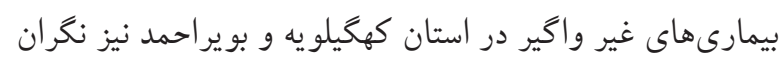
كننده است؛ هل درصد دجار خاقى و اضافه وزن، إب دروصد ابتلا

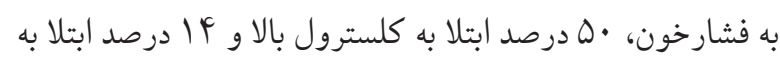

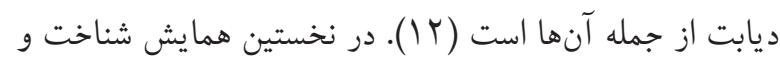

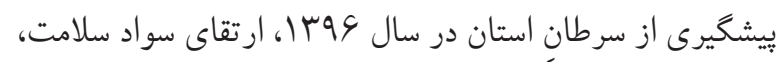

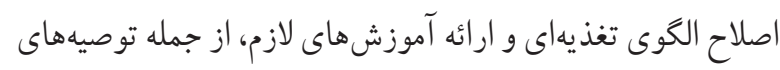
اصلى بوده است (r ا). از آنجا كه بر اساس نتايج سرشمارى سال

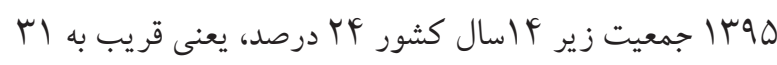

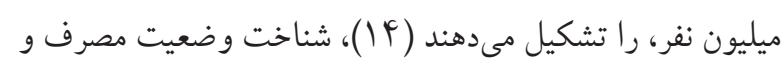

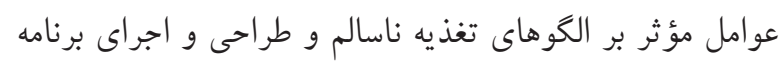

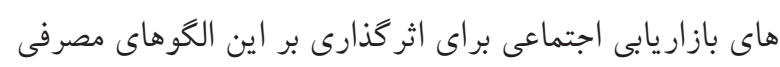

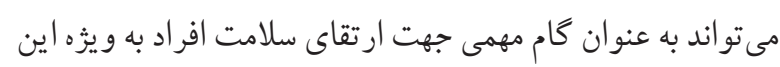

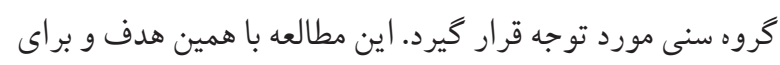
دست يابى به شناخت مناسبى از وضعيت مصرف غذاهاى آماده در

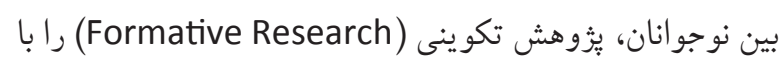

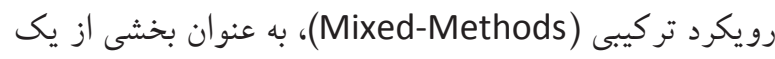

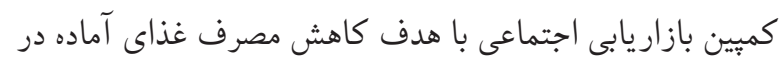
بين دانش آموزان مقطع متوسطه اول شهر ياسوج، طراحى و اجرا كرده است.

\section{مو اد و روشها}

در اين مطالعه روش يثزوهش از نوع تكوينى و رويكرد مورد استفاده نيز از نوع طرح تركيبى متوالى(Sequential Design) است. يثوهش تكوينى به فرايندى كفته مى شود كه با هدف تغيير رفتار

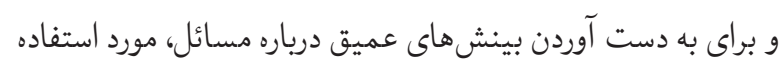

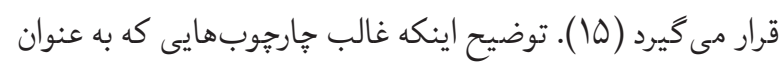
بلندمدت جانشين كليه ايدئولوثىها شده و مانند آيينهاى سلسله

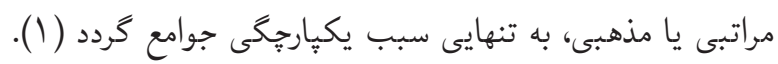

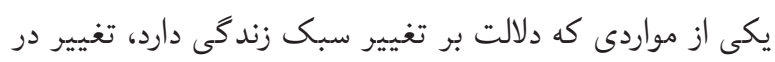
شيوه تغذيه است. در طى سالهاى اخير الخوى مصرف جهانى غذا

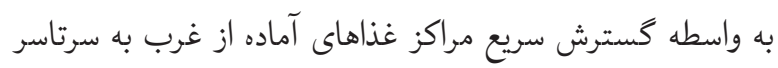

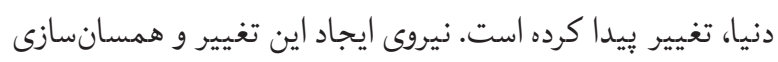
كسترده آنقدر قوى است كه ريتزر (Ritzer) تعبير مك دونالدسازى نيدي (McDolnalization) پمٍ بنزينها و حتى مراكز سلامتى مشغول ارائه اسنكها و ساير براي

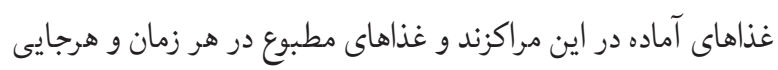
كه باشيد در دسترس است و ما در واقع، با هجوم غذاهاى آماده

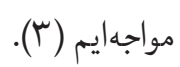
هرجند توافق عمومى بر سر تعريف غذاى آماده وجود ندارد

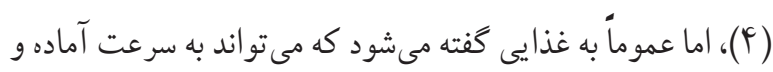

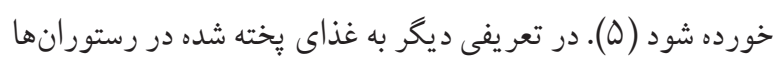

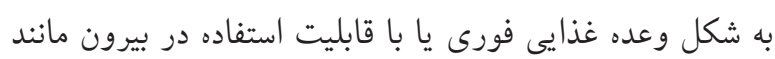

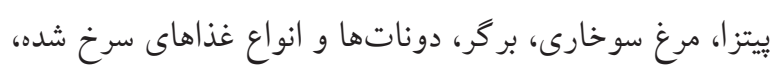

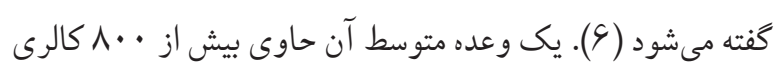

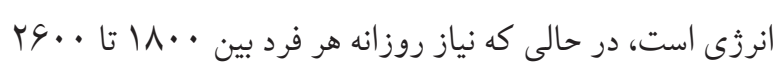
كالرى است (9). مطالعات متعددى اثرات منفى اين گونه غذاها

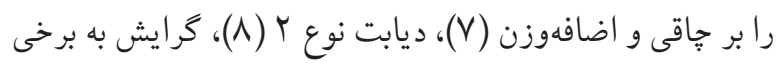

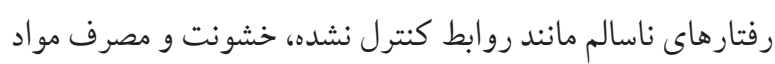

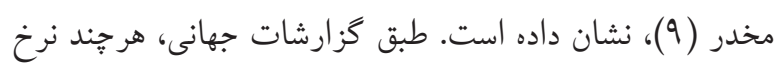
مرى و مير كودكان و نوجوانان كاهش بيدا كرده است اما به دليل عدم تغيير متغيرهاى مرتبط، تغييرى در وضعيت بيمارى هاى آنان رخ نداده است ( • (1).

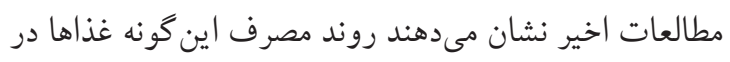

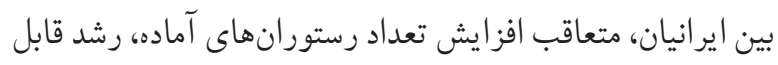

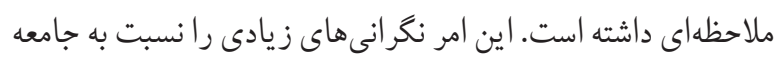


بر استفاده از نقاط قوت هر دو روش و غلبه بر نقاط ضعف آنها در

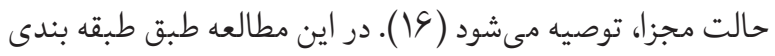

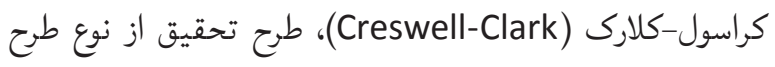

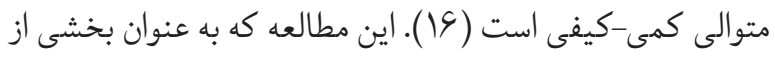

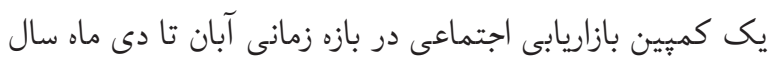

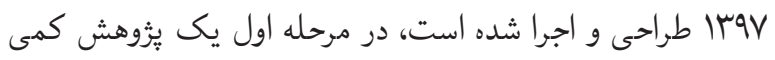

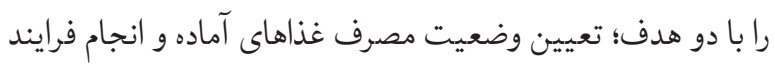
بخشبندى (Segmentation)، و در مرحله دوم يك مطالعه كيفى إنى

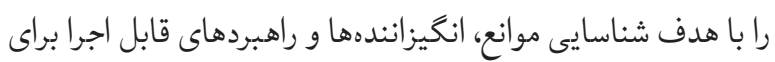

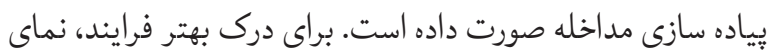
بصرى آن در شكل الرائه شده است.

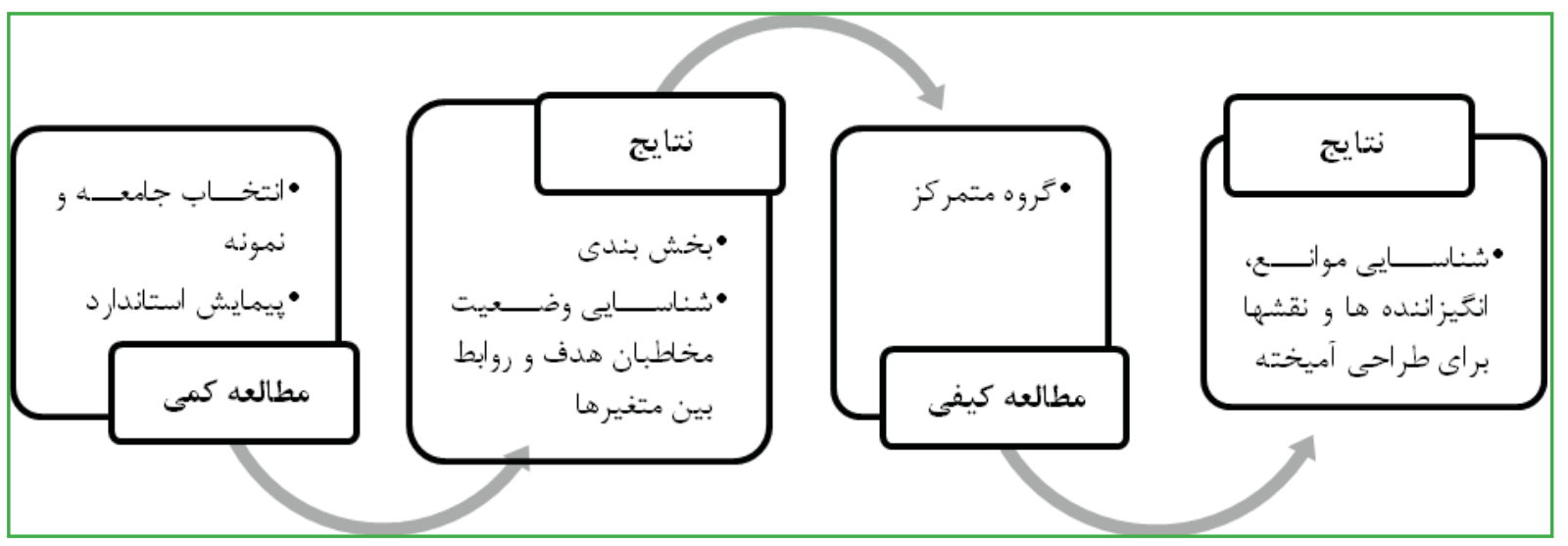

شكل ا. فرايند يثوهش تكوينى با رويكرد تحقيق تركيبى متوالى در اين مطالعه

راهنمايى براى طراحى مداخلات بازاريابى اجتماعى معرفى شدهاند اهميت زيادى براى انجام بثوهش هاى تكوينى قائل هستند. اندريسن تاكيد مي كند كه اين نوع يُوهش باعث اطمينان از (Andreasen) شناخت مصرف كننده و تمركز مداخلات بر او مى شود. صاحبنظران

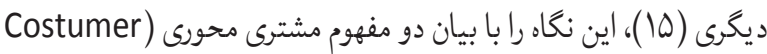

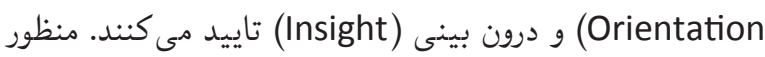
آنان از مشترى محورى، تمركز بر مخاطبان هدف براى فهم كامل

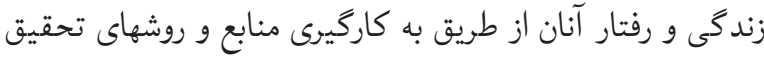
تركيبى است. در معيار درون بينى نيز نوعى شناخت را كه منجر

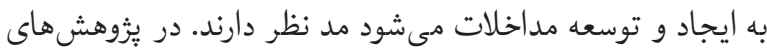
تركيبى مبتنى بر نگاه براخماتيسم (Pragmatism)، استفاده از هر دو روش تحقيق كمى و كيفى در يك مطالعه به منظور تاكيد
احتمالى از ادامه برنامه و تجز يه و تحليل كنار گذاشته شوند. رعايت ملاحظات سازمان همكار، از طريق بررسى تك تكى مو ارد مطالعه و

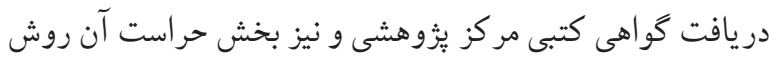
ديخرى براى رعايت اصول اخلاقى در اين بزوهش بوده بر است. الف ) مطالعه كمى برائ رعكا بيمايش به شكلى گسترده در بُزوهشهاى تكوينى مورد استفاده

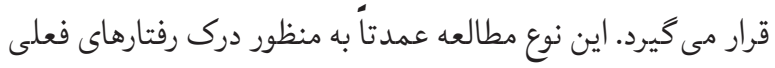
افراد و با هدف بخش بندى و هدف گذارى مخاطبان انجام مى شود.

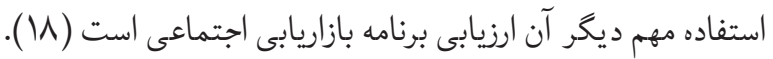

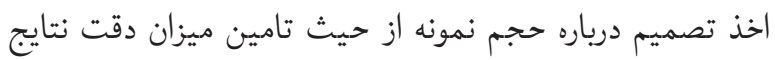

رعايت اصول اخلاقى و برهيز از آسيب زدن به مشاركت كنندكان

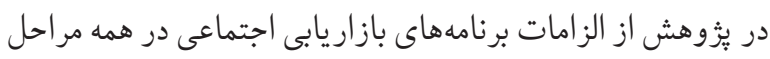

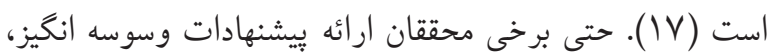
مانند يول، را از نظر اخلاقى مسالددار دانسته و معتقدند اين كار با ترويج مادى گرا يى و تقويت عدم تمايل افراد به كمك به خود بدون

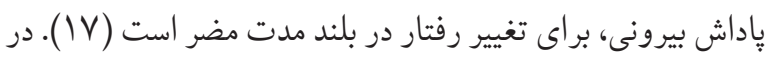
اين مطالعه براى رعايت نكات اخلاقى، مواردى همجيون داوطلبانه برى دئه بودن شر كت در برنامه و محرمانكى دادهها، در هر دو مرحله كمى و

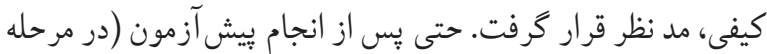

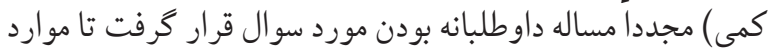


دانش، نكرش و رفتار مصرف كنند كان براى جمع آورى دادهها مورد استفاده قرار كرفته است. ب) مطالعه كيفى در مرحله دوم از بُزوهش تكوينى در بازاريابى اجتماعى، براى شناسايى

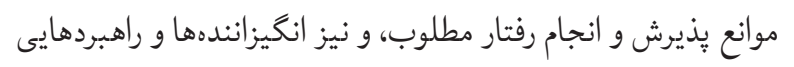

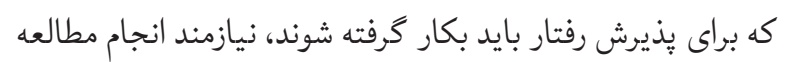

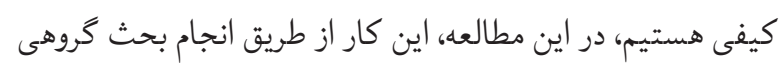

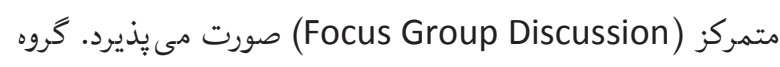
متمركز روشى ايدهآل براى به دست آوردن بينشهاى تازه دئ درباره

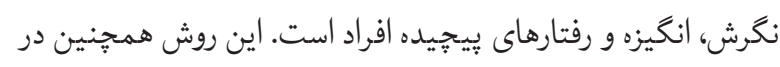
مواردى كه بين ادراك و بينش محقق و مخاطبان (مانند بازاريابان

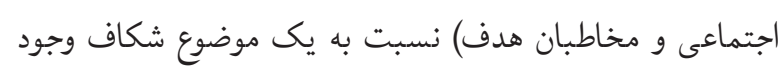

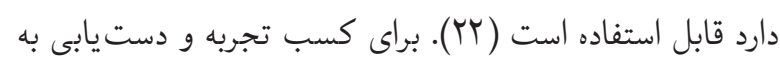
تركيبى مناسب، سه جلسه بحث آزمايشى به صورت تفكيكى (يسر

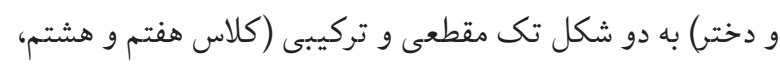

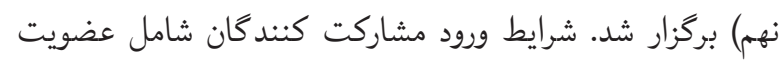
در بخش هدف كذارى شده كه اسامى آنها از ليست اعضاى نمونه استخراج شده بود (فرايند بخش بندى)، نظر مشاور و مدير مدرسه

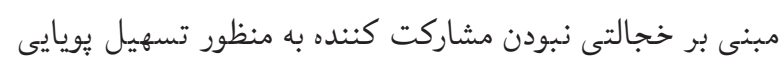

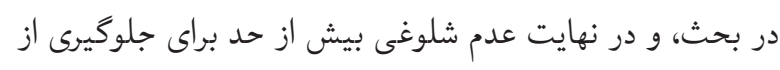

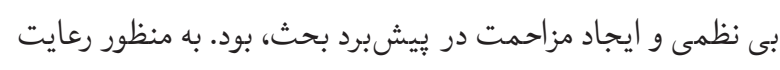

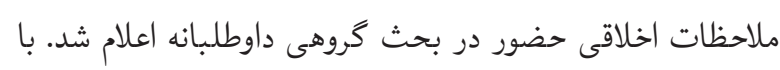

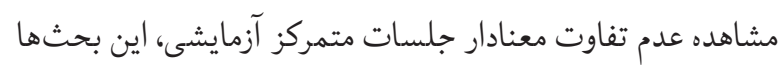

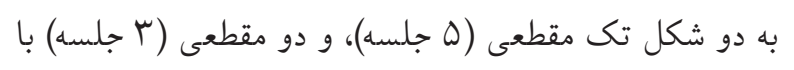

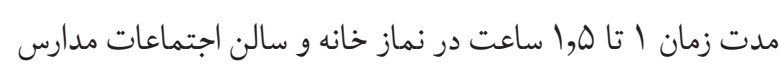
مورد مطالعه بركزار شد. به منظور اطمينان از كافى بودن تعداد

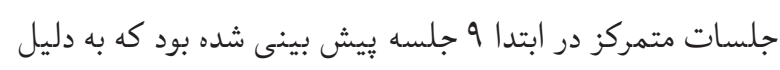
رسيدن به حالت اشباع در جلسه هشتم، به همين تعداد بسنده شد.

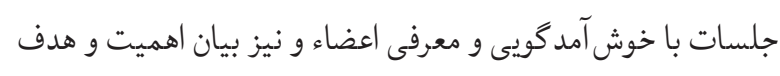

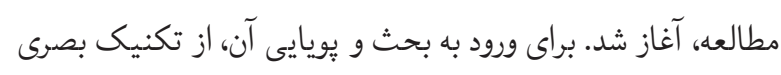
استعاره (Projective Technique)
نمونه گيرى و صرفهويى در مقدار وقت و هزينه از اهميتى خاص

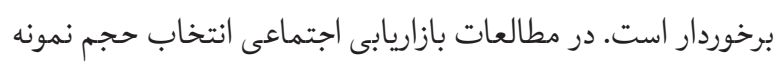

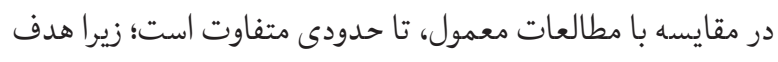

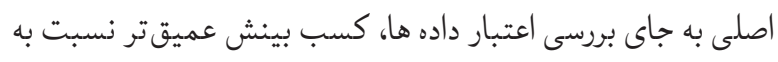

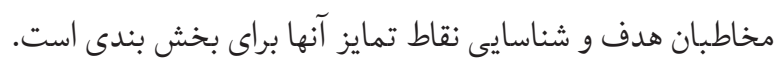
دالنيكار (Dolnicar) قاعده سرانگشتى حداقل •V برابرى تعداد

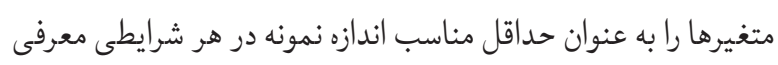

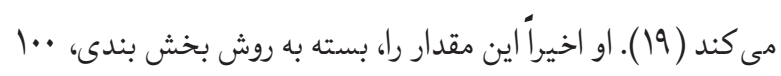
برابر تعداد متغيرها معرفى كرده و معتقد است كه اين افزايش اندازه

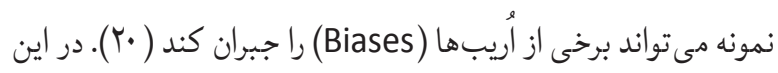

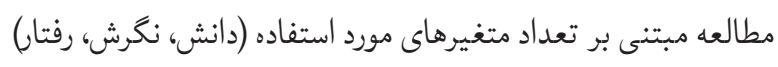

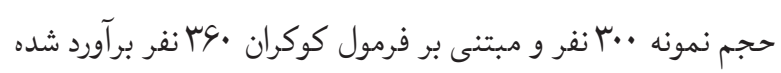

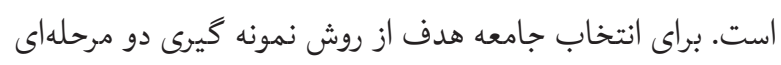
احتمالى استفاده شده است. در مرحله اول به صورت تصادفى از بين مدابن

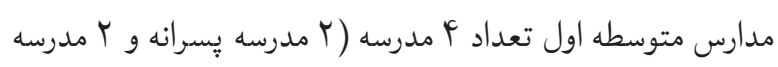
دخترانه) انتخاب و در مرحله دوم به شكل تصادفى از هر مدرسه

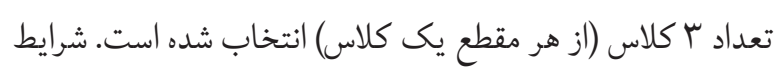
ورود به مطالعه در اين مرحله نداشتن بيمارى، نداشتن رثيم غذايى ئي

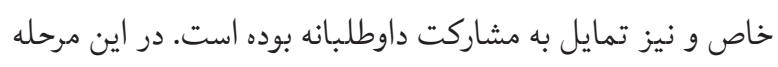
يرسشنامه استاندارد دانش، نكرش، رفتار كه مبتنى بر تئورى رفتار

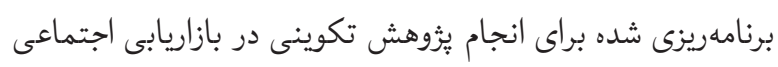
معرفى شده است ( (T)، با كمى متناسب سازى مورد استفاده قرار

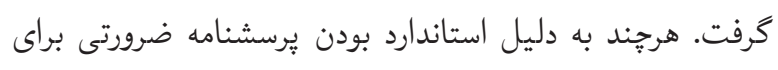

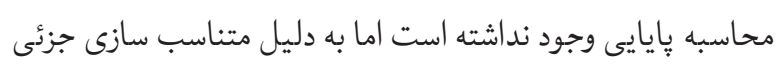

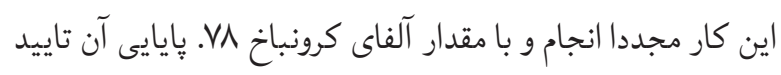

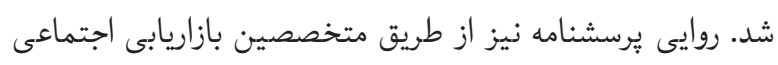

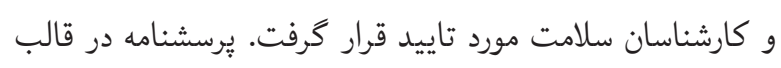

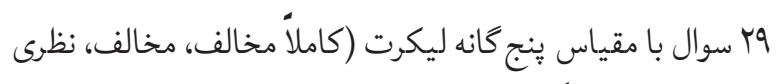

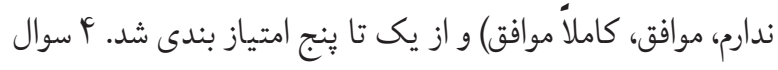

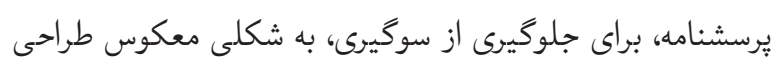

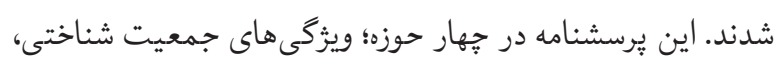


داده مىشود. براى اطمينان از تفسير درست دادهها، از يادداشت هاى حين انجام بحثها و نيز لحن اظهارنظر مشاركت كنند

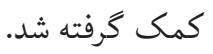

يافتهها

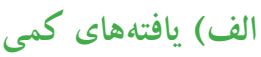
در مرحله كمى يرسشنامه دانش، نكرش، رفتار توسط بهr نفر از

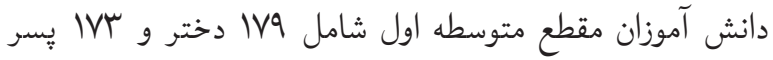
تكميل شد. از آنجا كه رفتار واقعى ييش بيش منوسط كننده بهترى نسبت به ساير متغيرها است و نيز براى دست يابى به شناختى مناسب از وضعيت مصرف، علاوه بر ويزگى هاى جمعيت شناختى (جدول ())،

جدول ا. ويثَى هاى دموگرافيك مخاطبان هدف

\begin{tabular}{|c|c|c|c|}
\hline \multicolumn{2}{|c|}{ جمع } & \multirow{2}{*}{\multicolumn{2}{|c|}{ متغير }} \\
\hline \multirow{2}{*}{ درصد } & \multirow{2}{*}{ فراوانى } & & \\
\hline & & 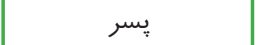 & \multirow{2}{*}{ جنسيت } \\
\hline$\Delta 1$ & 189 & دختر & \\
\hline $1 \cdots$ & ror & جمع & \\
\hline r/r & 118 & هفتم & \multirow{3}{*}{ مقطع تحصيلى } \\
\hline 每 & 118 & هشتم & \\
\hline ه/س & 111 & نهم & \\
\hline IV & 4. & كم (1) & \multirow{3}{*}{ 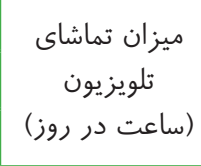 } \\
\hline$S Y / D$ & rt. & متوسط (1-r) & \\
\hline$r \cdot / \Delta$ & V9 & زياد (r>) & \\
\hline re/q & Ir. & لاغر (1)> & \multirow{4}{*}{ (بر مبناى شاخص جسمى } \\
\hline$\Delta r / \Lambda$ & $1 \wedge 9$ & نرمال (1) & \\
\hline $9 / 1$ & re & اضافه وزن ( •r - (ro & \\
\hline $1 / r$ & F & קاق (•r> & \\
\hline rF & $\wedge \Delta$ & هر دو شاغل & \multirow{3}{*}{ اشتغال والدين } \\
\hline SV & rus & يك نفر شاغل & \\
\hline 9 & r. & هر دو غير شاغل & \\
\hline
\end{tabular}

متغيرهاى دانشى، نكرشى و رفتارى مرتبط با مصرف غذاهاى

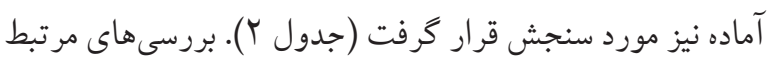
با نرماليته دادهها به كمك آزمون كولومو كروف - اسميرنف، نشان
اين كار با درخواست از مشاركت كنند گان جهت توصيف ويثگى هاى

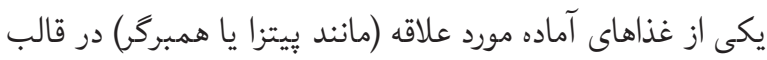
يك دوست، انجام شد. سيس بحث در دو بخش اصلى و به دو شكل سوالات باز و ايفاى نقش (Role playing) ادامه يافت. در بخش

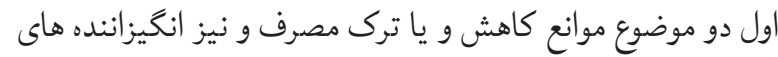
كاهش يا ترك مصرف غذاهاى آماده، مورد بحث قرار كرفت. در بخش دوم، نقش خانواده و مدرسه در كاهش يا ترك مصرف دانش آموزان مورد بحث قرار گرفت. بعد از هر سوال و تا مرحله اشباع، اجازه اظهار نظر و كفت و كو داده مىشد. براى حفظ نظم در ارائه نظرات و جلوكيرى از تقطيع كلام، به هر كدام از مشاركت كنند قطعه كاغذ و خود كارى داده شد تا در صورت نياز و بواى جلوگيرى از فراموشى نظر يا ايده خود را، قبل از فراهم شدن موقعيت اظهار

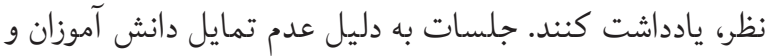

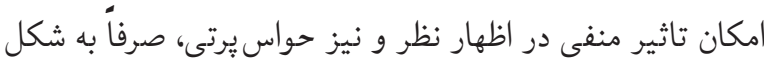
صوتى ضبط شد. اين كار به منظور راحتى و عدم خود سانسورى حين اظهار نظر، با بيشنهاد برخى از دانش آموزان در جلسات

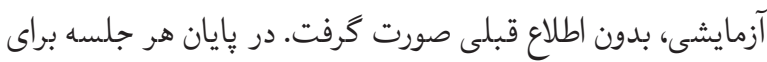

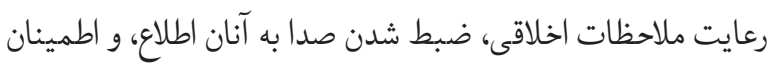
داده شد كه فايلها و ساير اطلاعات مرتبط براى تجزيه و تحليل محرمانه باقى خواهد ماند. در طول جلسات يكى از نويسند إنان كار اداره كننده جلسه و يك تسهيل گر (در اغلب موارد مشاور مدرسه) كار يادداشت بردارى موارد كلامى و غير كلامى براى تفسير بهتر

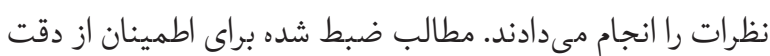

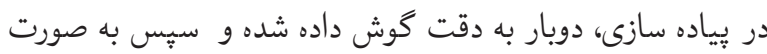

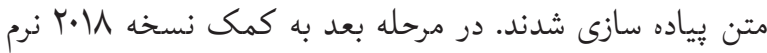
افزار مكس كيودا، تحليل محتواى كيفى انجام شد. براى اينكار از روش كد گذارى قياسى، توصيه شده توسط مايرينگ (Mayring) براى مواردى كه شناخت كافى از موضوع وجود دارد، استفاده شد دردي

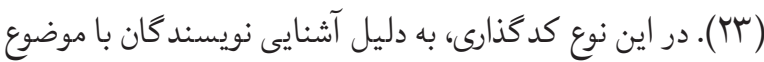

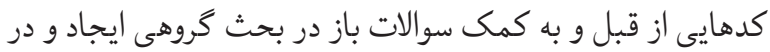

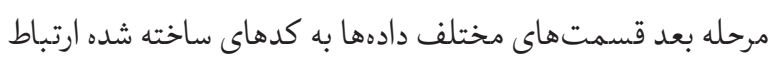




\begin{tabular}{|c|c|c|c|c|}
\hline Ï & $\mathrm{p}<\cdot / \cdot \Delta$ &.$/ 1 Y \wedge$ & $\cdot / \cdot \Delta V$ & اشتغال پِدر \\
\hline $\mathrm{P}$ & $p>\cdot / \cdot \Delta$ & /. &.$/ I F V$ & اشتغال مادر \\
\hline İ & $\mathrm{p}<\cdot / \cdot \Delta$ & $\cdot / \cdot V$ &.$/ \cdot 9$ & تحصبلات يدر \\
\hline $\mathrm{P}$ & $\mathrm{p}>\cdot / \cdot 1$ &.$/ \cdot 1$ &.$/ 1$ MA & تحصبلات مادر \\
\hline$\ddot{\mathrm{I}}$ & $\mathrm{p}<\cdot / \cdot \Delta$ & $\cdot \mid F V I$ &.$/ \cdot r q$ & شاخص توده \\
\hline$\ddot{\mathrm{I}}$ & $\mathrm{p}<\cdot / \cdot \Delta$ & $\cdot / \Delta \cdot \Delta$ &.$/ .9 r$ & بى ميلى به هاى \\
\hline $\mathrm{P}$ & $\mathrm{p}>\cdot / \cdot 1$ & $\cdot / \cdots$ &.$- /$ rs & دانش \\
\hline $\mathrm{P}$ & $\mathrm{p}>\cdot / \cdot 1$ & $\cdot / \cdots$ & $\cdot / \mu \cdot \varphi$ & نغرش \\
\hline
\end{tabular}

از نرمال بودن دادهها بر مبناى متغيرهاى مصرف (VFY..)، دانش ( ) (

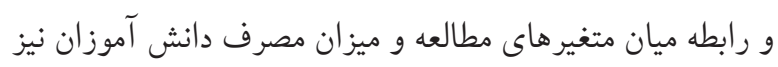
در جدول با ارائه شده است.

جدول r. رفتار مصرفى خود كَارشى دانش آموزان درباره

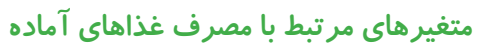

\begin{tabular}{|c|c|c|c|}
\hline \multicolumn{2}{|c|}{ جمع ( جم } & \multirow{2}{*}{ سطوح } & \multirow{2}{*}{ متغير } \\
\hline درصد & فراوانى & & \\
\hline FN/q & IVT & كم مصرف (س > ) & \multirow{3}{*}{ ميز ان مصرف (يكى مذشه) } \\
\hline$\mu \cdot / \varphi$ & $1 \cdot V$ & 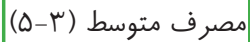 & \\
\hline$r \cdot / V$ & $v^{\mu}$ & مٍر مصرف (ه >) & \\
\hline$\Delta S / \Delta$ & 199 & خوشمزگى & \multirow{5}{*}{ دليل مصرف } \\
\hline$r Y / r$ & VA & 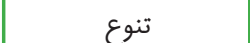 & \\
\hline $1 \cdot / r$ & rs & كمبود وقت & \\
\hline$\mu / \nu$ & 1r & قيمت & \\
\hline$V / 4$ & rs & ساير & \\
\hline $90 / 9$ & rur & با خانواده & \multirow{4}{*}{ شيوه مصرف } \\
\hline $1 N / \Lambda$ & 49 & با دوستان & \\
\hline $1 \cdot / 1$ & щ & تننها & \\
\hline$r / 4$ & 19 & ساير & \\
\hline$N / r$ & rq & ناهار & \multirow{3}{*}{ وعده مصرف } \\
\hline$\Lambda \mu / \Lambda$ & r9o & شام & \\
\hline$\wedge$ & rA & ساير & \\
\hline ir & is & 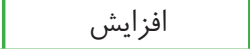 & \multirow{3}{*}{ (4) ماهه اخير ) } \\
\hline is & IfF & ثابت & \\
\hline is & IST & كاهش & \\
\hline
\end{tabular}

دانش آموزان دختر كلاس هشتمى مى گويد: (ا ديدن اين همه رستوران

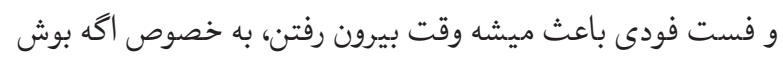

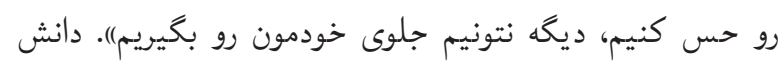
جدول سّ. همبستخى بين متغيرهاى مطالعه و ميزان مصرف فست

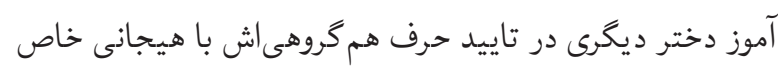

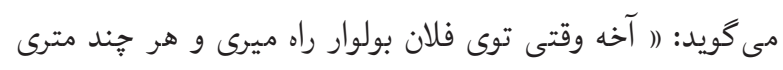
يه فست فودى هست، جِجورى آدم خودشو كنترل كنه؟ بالاخره يه جاش كم ميارى و ميرى تو سفارش ميدى).

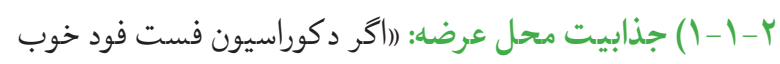

\begin{tabular}{|c|c|c|c|c|}
\hline معنادارى رابطه & معنا دارى سطح & p-value & همبستگى ضب & متغير \\
\hline $\mathrm{P}$ & $\mathrm{p}<\cdot / \cdot \Delta$ & $\cdot 1 \cdot \cdot 4$ & $\cdot / 1 \mathrm{~V}$. & جنسيت \\
\hline$\ddot{\mathrm{I}}$ & $p>\cdot / \cdot \Delta$ & $\cdot / \cdot \Delta r$ & $\cdot / 19 \wedge$ & مقطع تحصيلى \\
\hline$\ddot{I}$ & $\mathrm{p}<\cdot / \cdot \Delta$ & . & $\cdot / \cdot \vee 9$ & تلويزيون \\
\hline
\end{tabular}


خانكى اشاره مى كند و مى گويد: (ا مثلاً من بخوام با دوستام برم

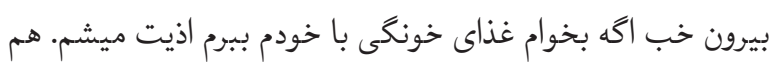
بردنش اذيت ميكنه هم مصرف كردنش. فست فود خيلى راحت

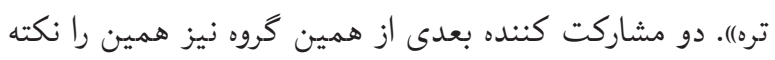

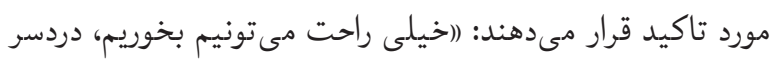

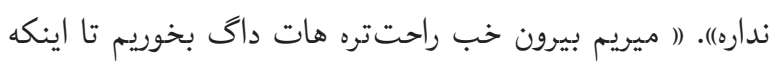

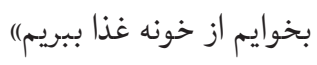

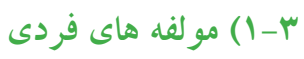
يكى ديكر از اين عوامل ويزگكى هاى روانشناختى خود فرد مصرف ماف كننده است. در اين بخش مخاطبان هدف به سه عامل اشاره كرده اند:

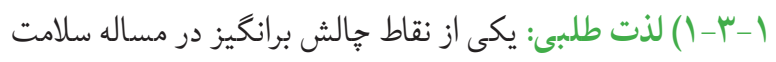
نحاه كوتاه مدت حاكم بر انتخابهاى نوجوانان است. به به دليل

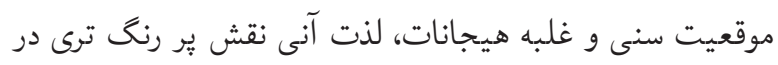

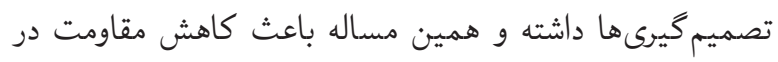

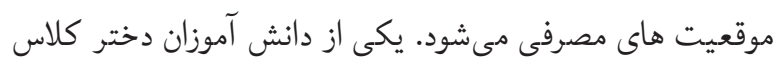

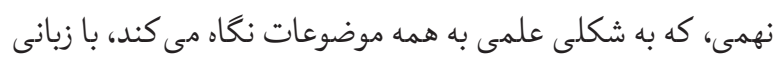

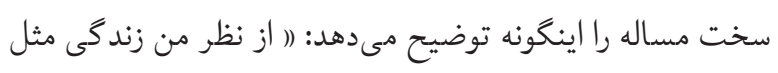

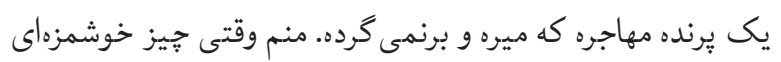

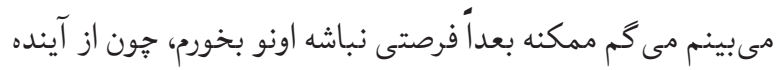

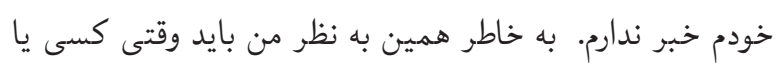
جيزى رو دوست داريم، كنارش باشيم يا ازش استفاده كنيم)،

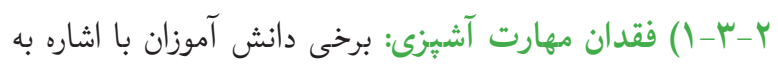

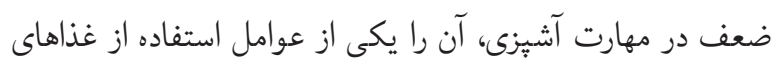
آماده بويزه هنحام تنهايى برشمردهاند: دانش آموز دخترى مى گیى مويد: (امن بلد نيستم غذا درست كنم، و خوب بيش اومده كه مامانم خونه نبوده و ناجار شدم كه فست فود استفاده كنم)،

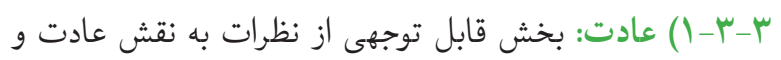

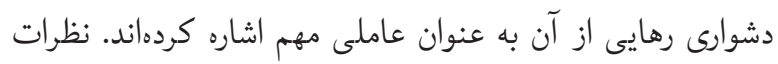

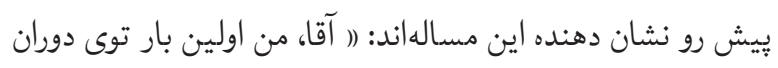

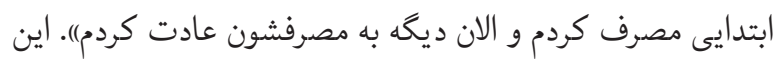

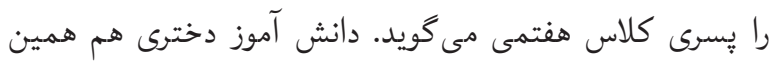

باشه حتى اگه غذاش بد باشه، كثيف هم باشه، آدم خيلى دوست داره

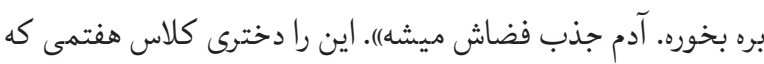

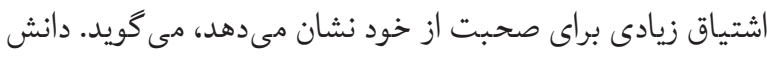

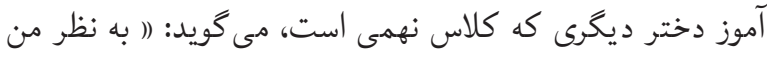

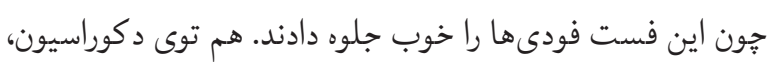
هم جاو هم طراحى شون. جوريه كه آدم جذبشون ميشها)

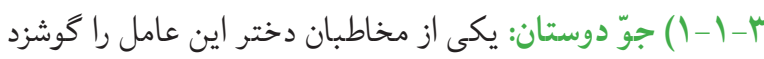
مى كند: (امن وقتى توى جمع نشستم- فرق نميكنه دوستان يا خانواده- و بقيه دارند مى خورند، خوب نمى تونم جلو خودمو بكيرم).

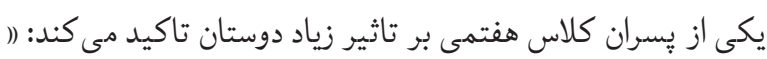
آقا! اوليش رفيقه، ميرن ميخرن، آدم تحريك ميشهان)

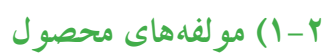
بخشى از مشكل به ويثگى هاى خود محصول يعنى غذاهاى فورى

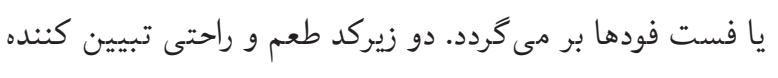
اين مولفه هستند.

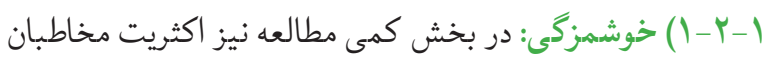
دليل اصلى مصرف خود را طعم و خوشمزگى اين گونه غذاها در مقايسه با غذاهاى خانكى عنوان كردند. در بحث گروهيى نيز اغلب

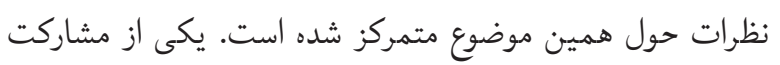

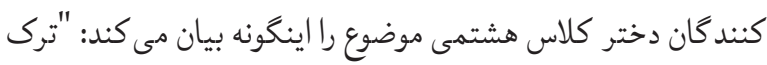
امكان پذير نيست، جون؛ يك، خوشمزه است. دو، خوشمزه است.

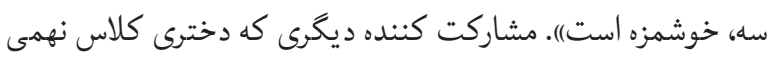
است و مصرف بالايى نيز دارد، موضوع را به شكل خاصى روايت

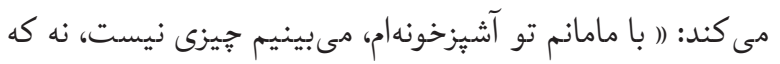

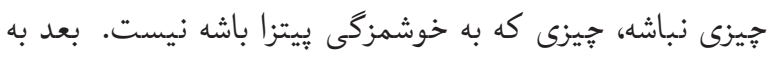

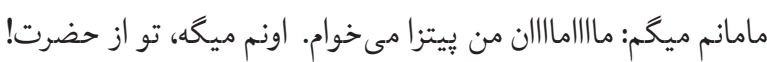

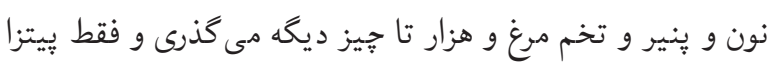

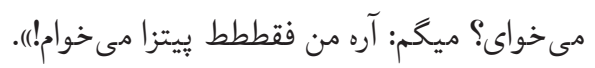

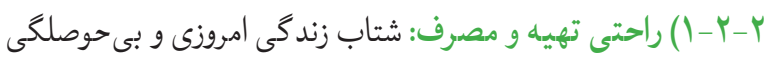
نسل كنونى، به ويزه جوانان و نوجوانان، يكى ديكر از علل گرايش به

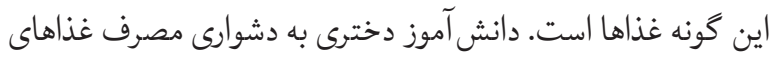


مساله سلامت براى آنان از اهميت خاصى برخوردار است. اين مساله

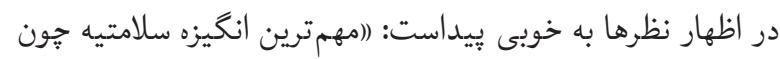
هيج كس نمى تونه اونو فراهم كنه، جز خودمون). اين را دانش آموز دختر كلاس هشتمى مى گويد.

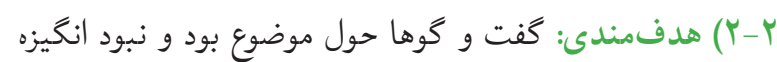

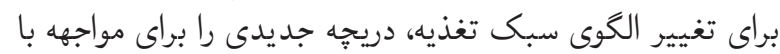

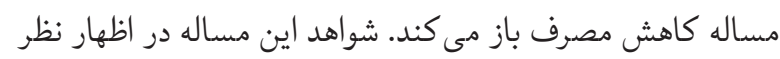
يكى از دانش آموزان دختر كلاس نهمى خودش راه ران نشان مى مدهد:

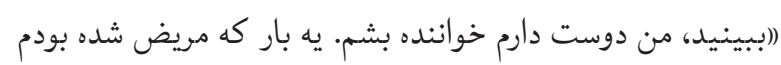

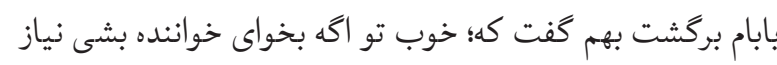

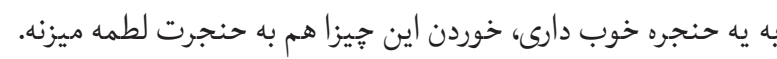

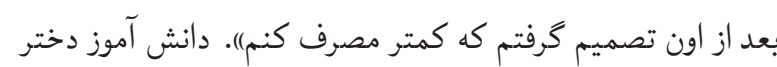

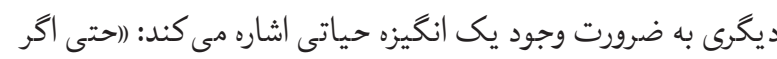
عوارض داشته باشه من باز هم مصرف مى كنم. تنها جيزى كه ميتونه منصرفم كنه اينه كه بدونم به تحصيلم ضربه ميزنه و نميتونم رشته دئه دئه مورد نظرمو قبول شم، اون موقع ديكه نمى خورم و هر جى مامانم

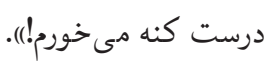

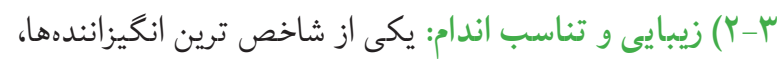

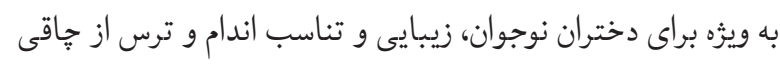

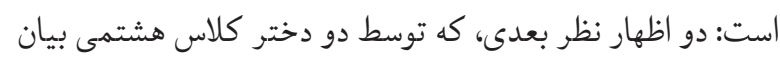

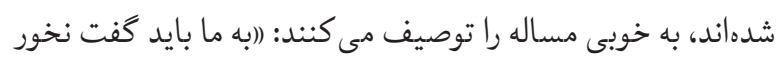
جاق ميشى! واقعاً براى دخترا جواب ميده. نمونه ش خواهر بزرى خودم)؛؛ (امن وقتى فكر مى كنم كه ممكنه لباس اندازهام كير نياد نابود مى شم. اينه كه باعث مىشه احتياط كنم و كمتر بخورم ).

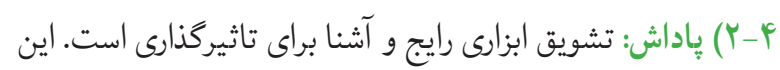
مساله در اظهار نظرهاى مشاركت كنند كان هم تاييد شده است: مخاطب پِسرى مى گويد: (انمى خوام از واقعيت فرار كنم، به نظرم

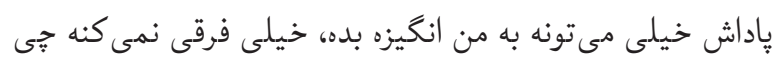

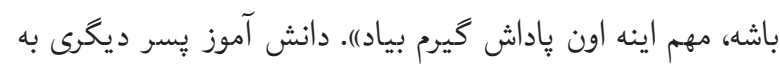

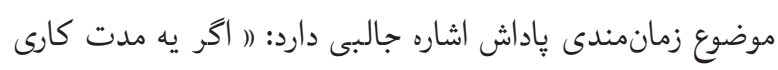
رو انجام نديدم اون عادت ترك ميشه بهتره به همون مقدار زمان
عقيده را دارد: (( بخاطر اينه كه عادت كرديم و سخته ترك كردنش)). مخاطب دخترى كه در اغلب اظهار نظرهايش به تربيت خانواد گیى ارجاع مىدهد، معتقد است: (ا به نظر من به خانوادهها بر ميكرده،

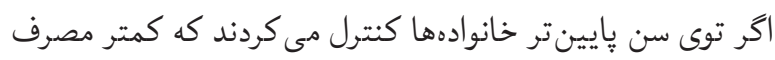
كنيم، خوب ديخه عادت نمى كرديم)

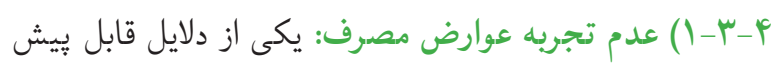

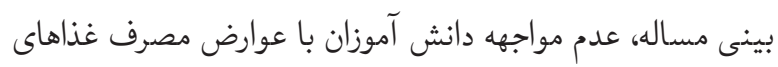

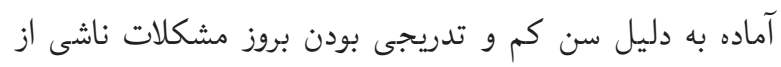

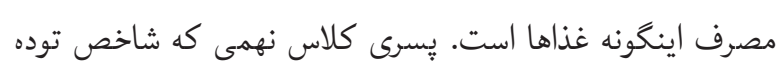

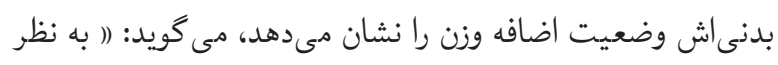

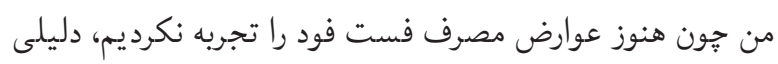

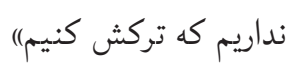

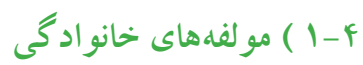

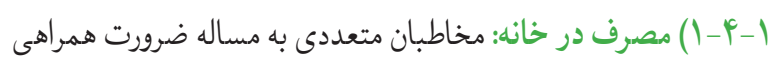
براى يرهيز از انجام يك رفتار اشاره داشتند. يكى از مشاركت كنند كان دختر گروه مى گويد: (ا من بابام كارش همينه! هر وقت مياد خونه

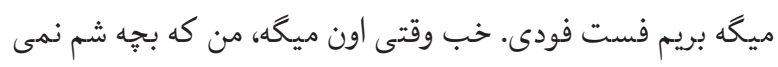

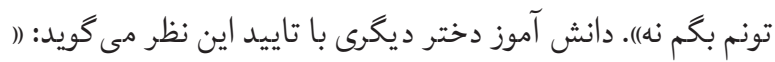

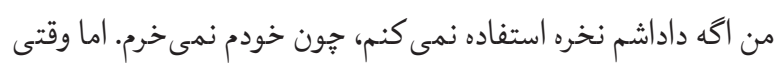

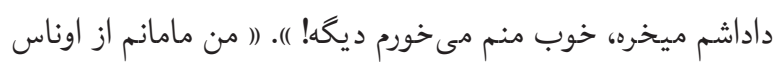

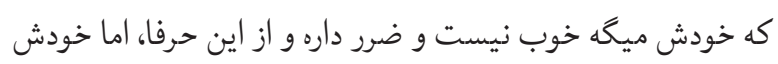
ميخوره!)؛ اين را يكى ديكر از دختران كلاس هشتمى بيان مى كند.

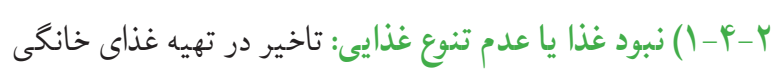

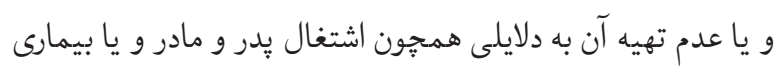
مادر از ديكر عوامل اين مساله است. يكى از دانش آموزان دختر

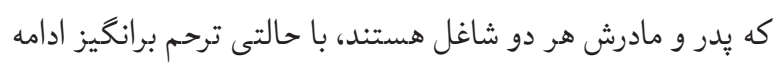
مىدهد: (اوقتى كسى خونه نيست، جيزى نيست، حالى نيست...). دوستش اما نظر ديكرى دارد: (اغذاى خونكى خسته كننده و تكرارى

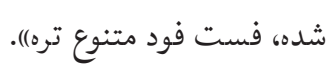

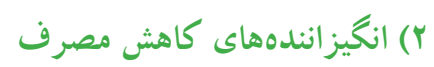
(Y-1) سلامتى و تندرستى: عليرغم سبك زند گیى هيجانى نوجوانان، 
" (بايد روزنامه ديوارى و يوستر درباره مصرف اين غذاها بزنيم، البته

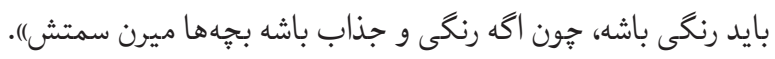

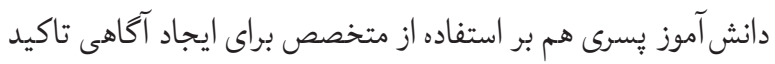

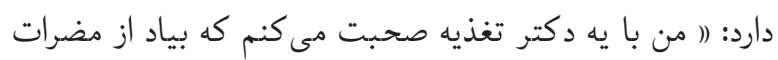

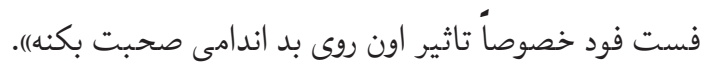

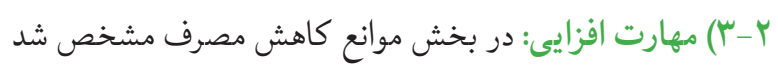

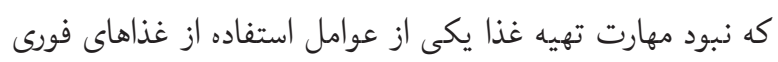

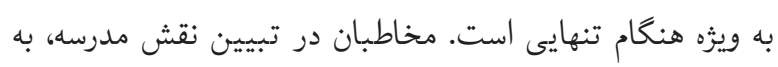
شكلى ناخوادكاه اين وظيفه را بر دوش مدرسه قرار مىدهند. سه تهنه اظهار نظر بعدى در اين رابطه است: دخترى كلاس نهمى مى گیى نهيد:

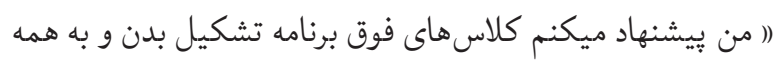
بجهها آشيزى، به خصوص طرز تهيه غذاهاى اركانيك رو ياد بدن)؛؛

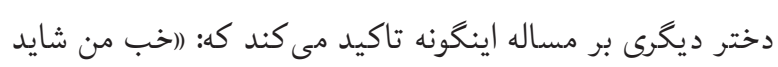
دوست داشته باشم كالباس بخورم اما بلد نباشم جطورى كالباس دئس با كوشت سالم درست كنم. مربى بهداشت مىتونه طرز تهيه اينا

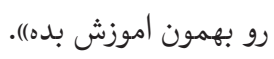

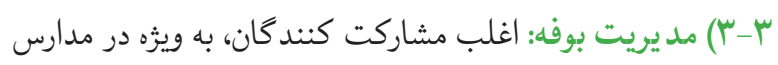
يسرانه، مديريت بوفه را عامل مهمى در تغيير رفتار مصرفى خود

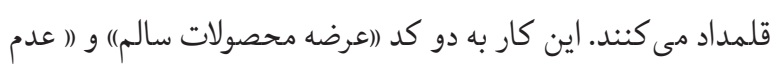

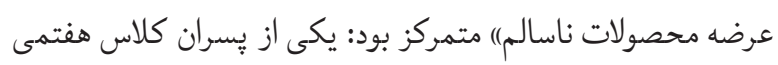
مى گويد: (بوفه مدرسه داداش من محصولات سالم ميده، مثل آش و و

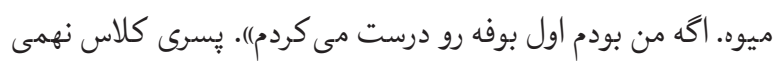

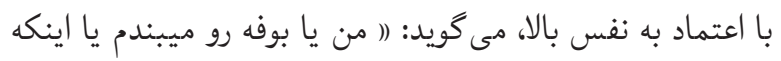

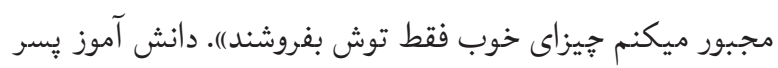

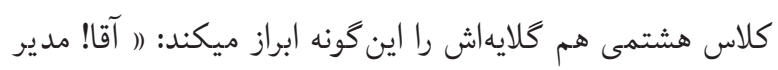
ميكه مصرف نكنيد، اما بوفه داره غذاهاى مضر رو توزيع ميكنها)

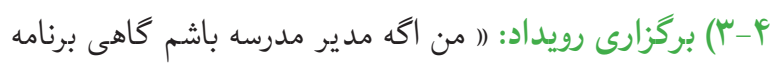

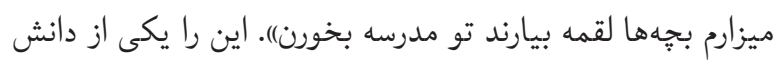

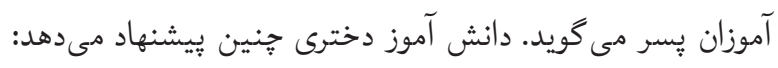

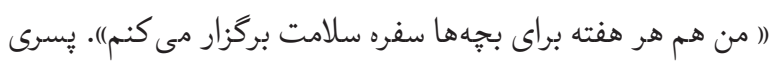
كلاس نهمى عقيدهاش را اينطور بازگو مى كند: (ا به نظر من بهترين
تعيين كنيم و جايزه بديم ).

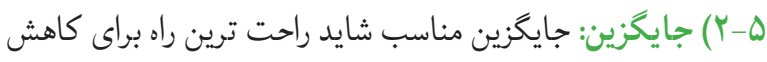

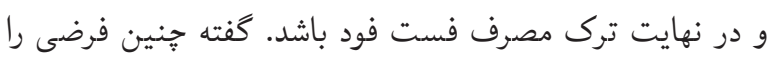
تاييد ميكنند: (ابه نظرمن هنوز هم مى تونيم با جايكزين هاى ديكه لذت ببريم)؛؛ اين را دخترى كلاس نهمى مى گويد. دخترى كلاس

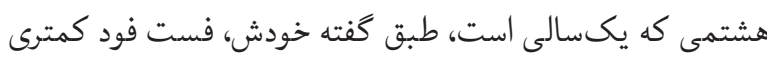
مصرف مى كند، مى گويد: (ا من سعى مى كنم جايكزين كنم. الان هم

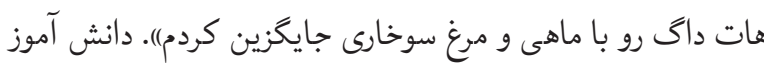
دخترى كه تاكيد دوستش بر لذت فست فود را مىبيند اين كونه

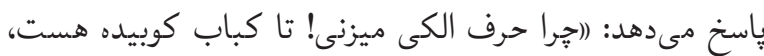
קُرا فست فود؟)).

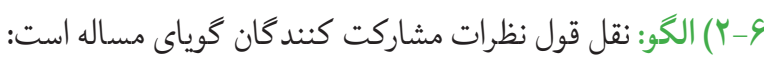

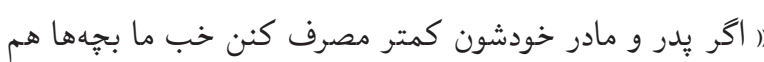

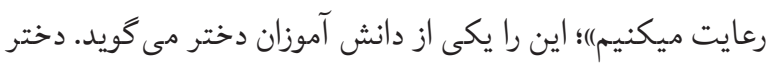

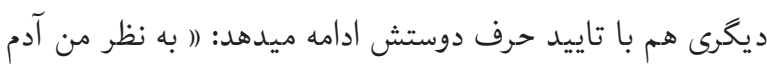

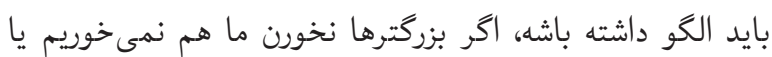

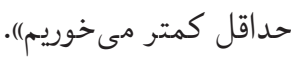
(Y-V

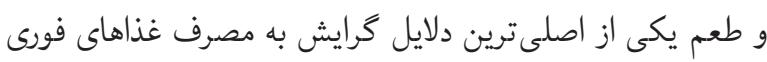

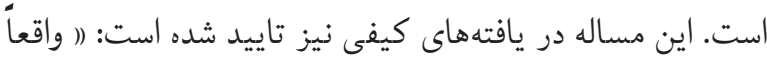

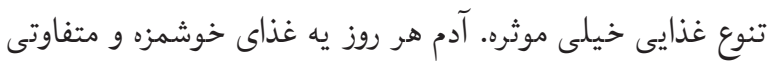
بخوره خوب ديكه هوس فست فود نميكنه)). مخاطب ديكرى هـم هونم

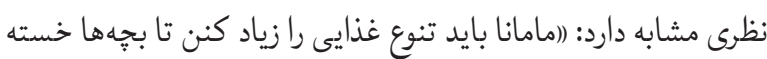
و دلزده نشن)؛ اين را دانش آموز دخترى مى گويد. (Y) - نقش ملدر سله

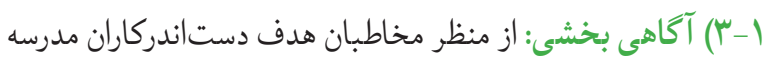

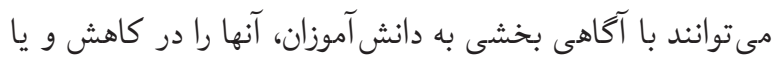

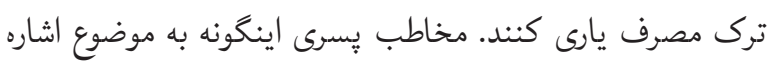

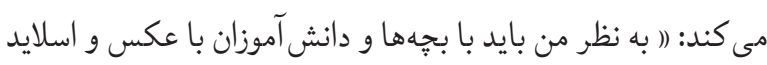

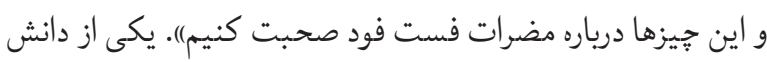
آموزان دختر جذابيت ارائه را مورد تاكيد قرار مىدهد و مى گیى ئديد: 
ميتونه كارى بكنه كه من فست فود نخورم). همكلاسى راهكارش اين است: (بين اعضاى خونه علايقشون رو بيدا مى كنم و براى هر روز يك غذاى مشترك درست مى كنم)). دخترى كلاس رهن هفتمى هم مى گويد: (امن سليقه بجهها رو مى برسم و طبق اون

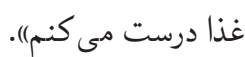

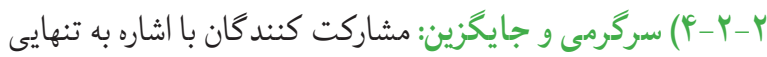
و بى حوصلكى به عنوان عوامل موثر بر مصرف، سركرم شدن را راهى براى برهيز و يا كاهش مصرف عنوان مى كنند. دانش آموز

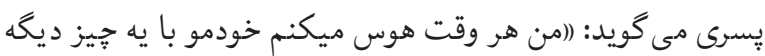

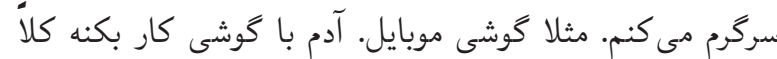

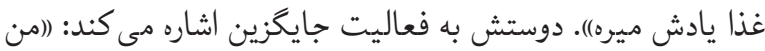
سعى مى كنم روزى كه فست فود مصرف مى كنن فعاليت ديخهاى

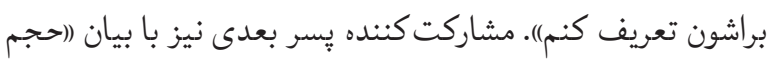

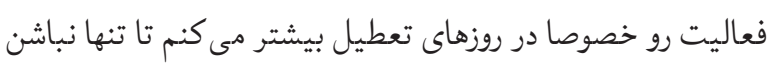
كه هوس كنن)،، اين مساله را تاييد مى كند.

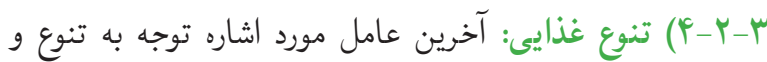
سليقه غذايى اعضاى خانواده است. مشاركت كننده دخترى اين

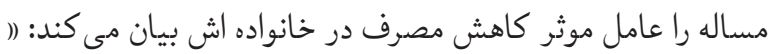

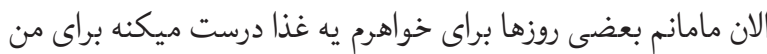
هم يه غذا، جون علاقه مون با هم متفاوته. اين باعث ميشه خيلى

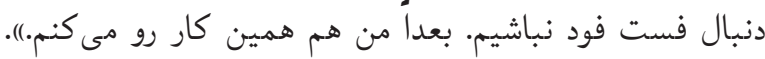
دخترى كلاس هفتمى هـم مى گويد: (ا واقعاً تنوع غذايى خيلى موثره.

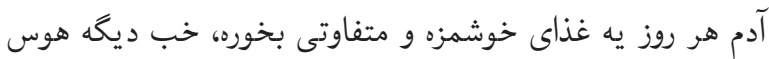

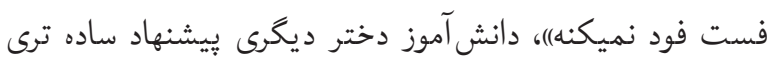
دارد: (ا من اگه جاى مامانم بودم همه غذاهايى كه درست مى كنم

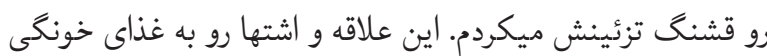

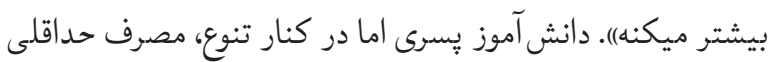
را كوشزد ميكند: (ا تنوع غذايى رو بيشتر ميكنم و اخرم ناجار به مصرف شديم، مقدارش رو كم ميكنم)،

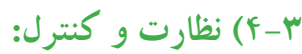

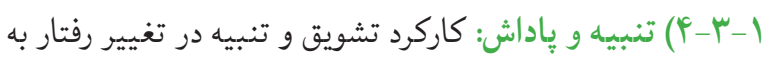

كار مدير مدرسه ميتونه فعاليت و مسابقات با محوريت زندگى

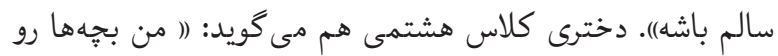

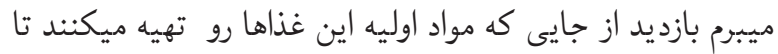
خودشون ببينن از جى درست ميشن).

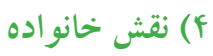

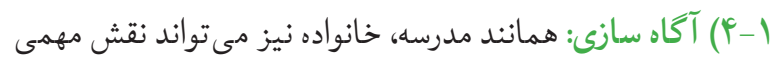
را در آكاه سازى مخاطبان هدف بر عهده بخيرد. مشاركت كنندگان

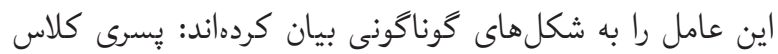

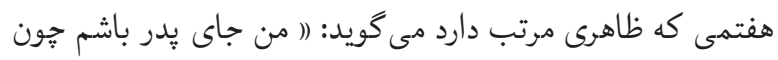

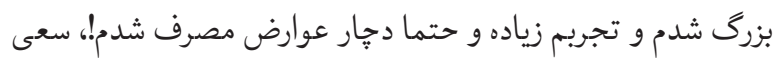
ميكنم با بيان تجربيات بجه هام رو قانع كنم)ا. مشاركت كنند كان

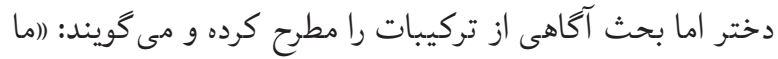

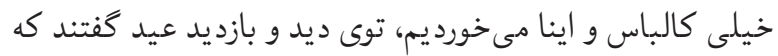

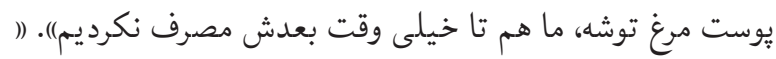

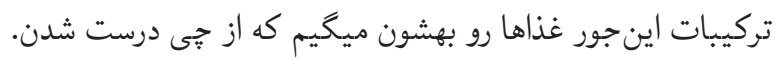

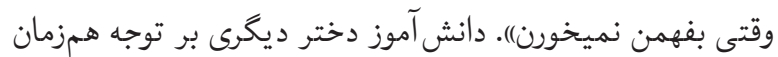

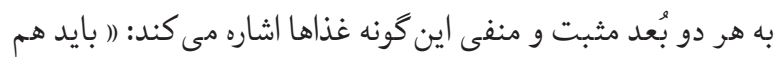

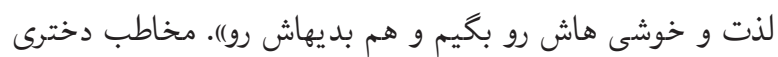

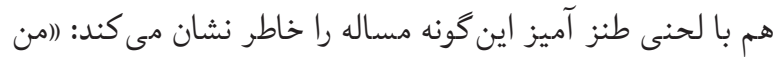
مى خوام جاى مامان خودم حرف بزنم!: ببين عزيزم! اين كالباس

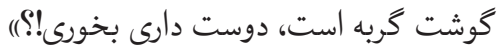

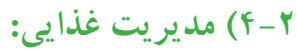
1 (Y-Y-Y) تهيه غذاى مورد علاقه: اصل تهيه غذاى خانكى موضوع مهمى است، به خصوص در مواردى كه والدين هر دو شاغل هستند. دانش آموز دخترى با گلايه از اين وضعيت مى كويد: (اركه مامانم

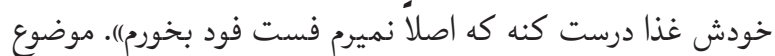
مهم ديكر توجه به طعم و خوشمزگى غذاى خانكى است. علاوه بر اظهار نظرهاى متعدد در بحث گروهى، بيمايش كمى نيز نيز نشان از نقش اصلى و انكار نايذير خوشمزگى در مصرف غذاهاى آماده داشته است. همين مساله مى تواند تاكتيكى براى كاهش مصرف تصنى باشد: دخترى كلاس هشتمى مى گويد: (اغذاهاى خوشمزه مامان 
كرده و شكست خورده حرفش رو بيشتر باور مى كنيم و اثرش هم بيشتره)). يسرى كلاس هشتمى نيز با ذكر خاطره اى ميزان

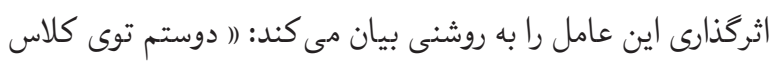

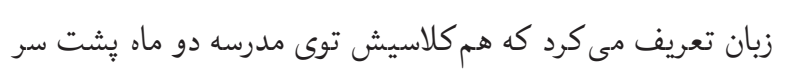

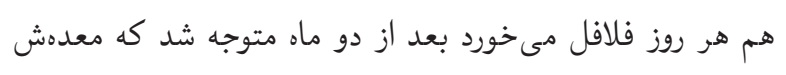

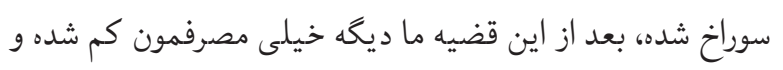
هر ينج شش ماه يه بار مى خوريم)|.

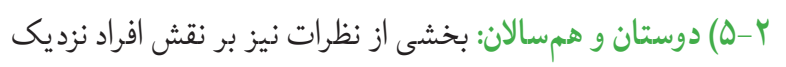

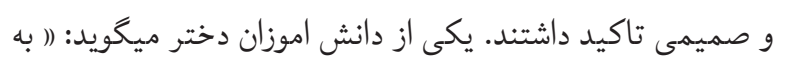
نظر من كسى هم سن و هم سنخ خودمون باشه بيشتر رو بجهها تاثير مىذاره)). دختر ديكرى همين مطلب هن را تكرار مى كند: (( منم

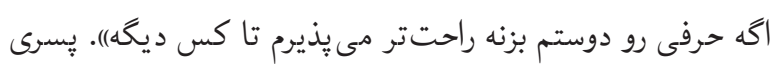

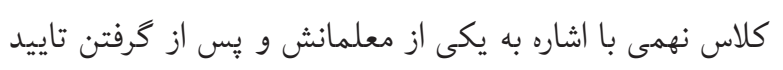

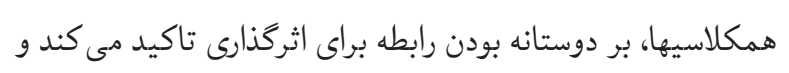
مى گويد: (ا كسى كه زبون ما رو بهتر بفهمه و بلد باشه با بجهه بها ارتباط بكيره، مثل آقاى يكانه).

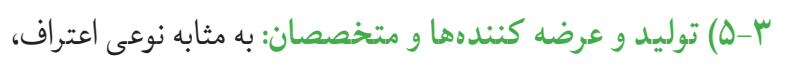
وقتى كسى كه در موضوعى ذينفع است به جنبههاى منفى آن

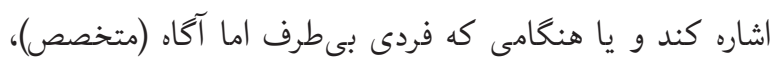

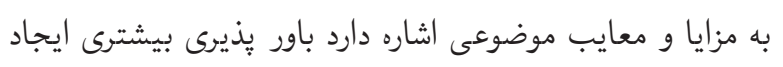

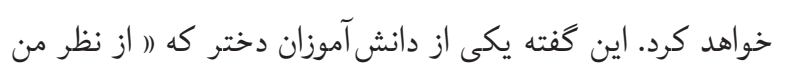

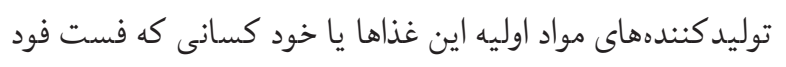
مى فروشند اثركذارترند)،، مبتنى بر همين باور است.

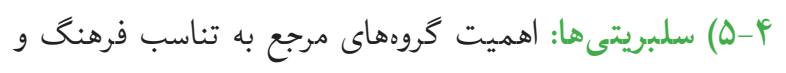

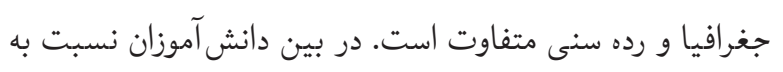

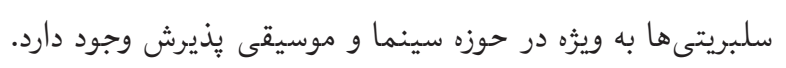

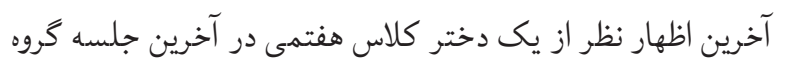

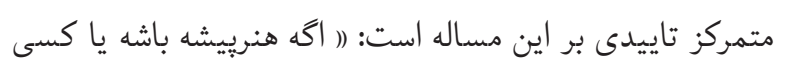
كه دوسش داريم، اثرخذارتره).
ويثزه در سنين نوجوانى موضوعى تاييد شده است. مخاطبان هدف كه خود نوجوان هستند، به شكل هاى مختلفى اين موضوع رونى را تاييد

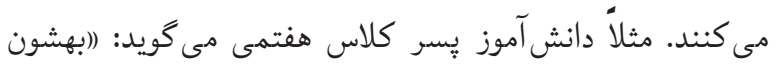
مى كيم اكه نخورين مى بريمتون هارك، سينما، شهربازى)، مجدداً

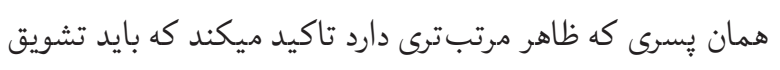

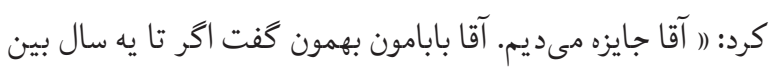

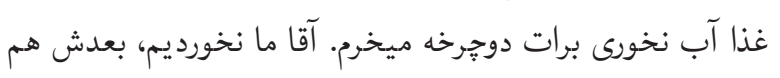

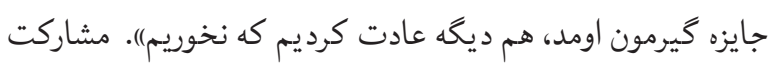

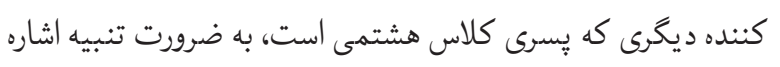

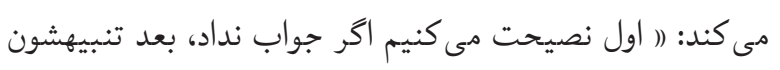
مى كنيم و يول توجيبى بهشون نميديم)".

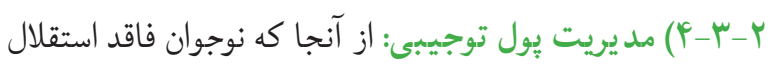
مالى است، استفاده از اين ابزار مى تواند در تغيير رفتار او موثر إنى باشد. دانش موز پِسرى مى گويد: (همه اين يولها از تو جيب بـ بابا

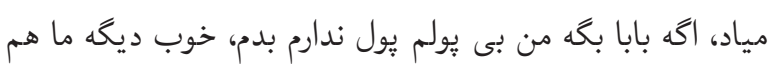

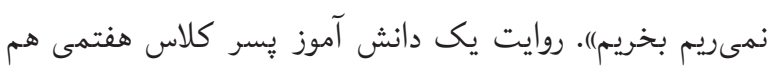

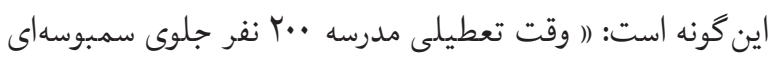
صف مىبندند، اخر يول توجيبى محدود باشه يا توى كارت باشه

$$
\text { بهتره و كمتر خرج ميكنن). }
$$
ها هانال هاى توزيع مناسب يكى از مولفههاى آميخته بازاريابى اجتماعى در اجراى مداخلات مات مات تعيين كانالهاى توزيع محصولات و يِام هاى كميّين است. بنابراين

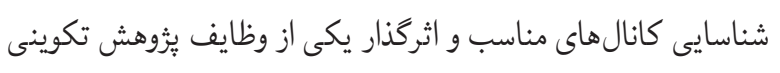
محسوب ميشود. در اين مطالعه و در فاز كيفى، علاوه بر تعيين موانع و انخيزانندهاى كاهش مصرف، انتقال دهند مان موثر بيام جهت تغيير الكوى مصرف شناسايى مى شوند. اين كانال ها عبارتند از:

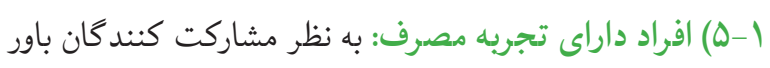
يذيرى وقتى حاصل مىشود كه شخص توصيه كننده، خود، واقعاً

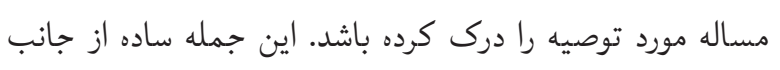

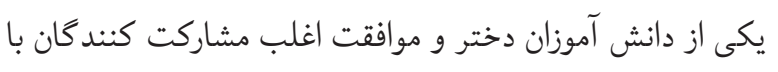

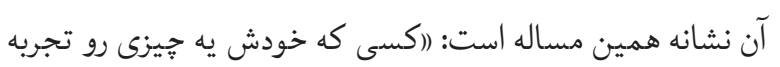




\begin{tabular}{|c|c|c|}
\hline - & تجربه كننده عوارض & \multirow{4}{*}{ كانال هاى توزيع } \\
\hline- & دوستان و همسالان & \\
\hline - & كتخصصين و عرضه & \\
\hline - & سلبريتى ها & \\
\hline
\end{tabular}

بحث و نتيجه كيرى

اين مطالعه، به عنوان بخشى از يك كميين بازاريابى اجتماعى، و با هدف كسب بينش هاى مرتبط با مصرف غذاهاى آماده در بين دانش آموزان متوسطه اول، انجام شده است. از آنجا كه در رويكردهاى تركيبى توجه همزمان به نمايايى (Representativeness) و هدفمندى (Purposiveness) ضرورى است (צا))، اين كار در مرحله كمى به كمك معيار .|l برابرى حجم نمونه، و در مرحله كيفى با رعايت شاخصهاى انتخاب مشاركت كنند گان در جلسات متمركز، صورت كرفته است. در مرحله تحليل تركيبى متوالى نيز دو فرض تحليل آمارى در بُعد كمى، و تحليل روايتى و تفهم در بُعد كيفى از طريق تحليل همبستگى در فاز كمى و تحليل محتوا در فاز كيفى تحقق يافته است. در ادامه به شكلى مبسوط تر بحثهاى مرتبط با تحليلها در هر دو مرحله ارائه مىشود: در مرحله كمى، يافته ها وضعيت مصرف را تا حدودى روشن مى كند. به عنوان مثال نتايج سه عامل اصلى مصرف را به ترتيب خوشمز (D/ ) معرفى كردهاند. لذا هر گونه مداخله تغذيهاى براى ارتقاى سلامت در اين حوزه بايد بهبود شيوه طبخ و طعم غذاهاى خانكى را مد نظر قرار دهد. در تبيين متغير نحوه مصرف سه عامل خانواده (9/90 درصد)،

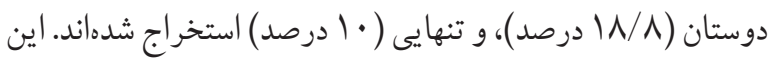
نتايج با برخى يافتهها (YY) همخوانى اما با يافتههاى سئو، لى و نام كه در مدارس متوسطه كره جنوبى انجام (Seo, Lee and Nam) كرفته است (YO)، ناهمخو انى دارد. به نظر مىرسد دليل اين مساله شكل مصرف در فرهنگ كره باشد، جايى كه مصرف فست فود به عنوان يك رو يداد ويثه به جاى بخشى از يك رزيم غذايى روزمره- كه با ديدار دوستان يا بر كزارى مراسم جشن مرتبط است - يذيرفته شده
جدول \&. درون مايه هاى اصلى و فرعى بحث گَروهى متمر كز

\begin{tabular}{|c|c|c|}
\hline كدها & درون مايه فرعى & درون مايه اصلى \\
\hline تعدد مراكز & \multirow{3}{*}{ محيط } & \multirow{10}{*}{ موانع كاهش/ترك مصرف } \\
\hline جذابيت رستوران & & \\
\hline جوّ دوستان & & \\
\hline مصرف - عدم مصرف خانواده & خانواده & \\
\hline خوشمزگى & \multirow{2}{*}{ محصول } & \\
\hline راحتى تهيه و مصرف & & \\
\hline لذت طلبى & \multirow{4}{*}{ فرد } & \\
\hline فقدان مهارت & & \\
\hline عادت & & \\
\hline عدم تجربه عوارض & & \\
\hline عبرت و تجربه & سلامت و تندرستى & \multirow{5}{*}{ | } \\
\hline اقتصادى- غير اقتصادى & هدفمندى و انكيزه & \\
\hline جاقى- زيبايى & زيبايى و تناسب اندام & \\
\hline- & هِاداش و تنبيه & \\
\hline- & جايگزين مورد علاقه & \\
\hline مرجع اثر گذار & \multirow{2}{*}{ آكاهى بخشى } & \multirow{9}{*}{ نقش مدرسه } \\
\hline جذابيت & & \\
\hline شود مديريتى (محاسبه & \multirow[t]{2}{*}{ مهارت افزايى } & \\
\hline فعاليت ورزشى / آشيزى & & \\
\hline صبحانه & \multirow{3}{*}{ برگزارى رويداد } & \\
\hline سفره سلامت & & \\
\hline ساير فعاليت ها & & \\
\hline مديريت بوفه & \multirow[b]{2}{*}{ نظارت و كنترل } & \\
\hline 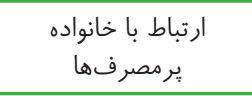 & & \\
\hline تنوع & \multirow{4}{*}{ مديريت غذايى } & \multirow{8}{*}{ نقش خانواده } \\
\hline غذاى مورد علاقه & & \\
\hline سرگرمى و جايخزين & & \\
\hline تنوع & & \\
\hline بيان تجربيات & \multirow{2}{*}{ آكاه سازى } & \\
\hline استفاده از عامل كليدى & & \\
\hline مديريت يول توجيبى & \multirow{2}{*}{ نظارت و كنترل } & \\
\hline ياداش و تنبيه & & \\
\hline
\end{tabular}


در برنامه هاى مختص كود كان و نوجوانان در ايران و شيوع بيشتر اين سبك مصرف در جوامع غربى، از دلايل اين ناهمخو انى باشد. هرجند بين

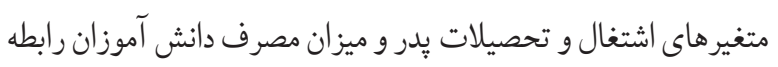

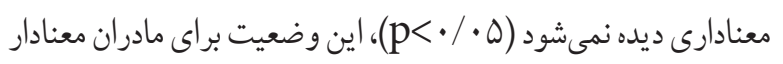

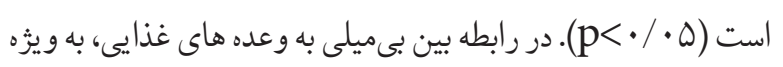

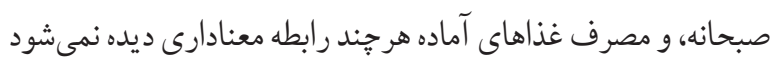

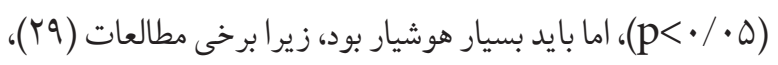

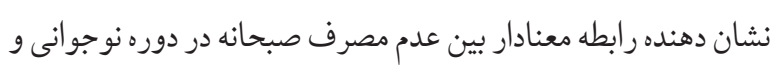

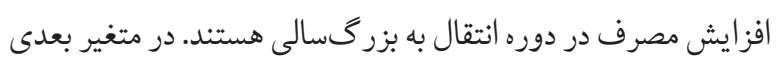

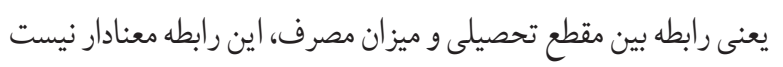

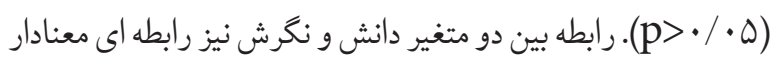

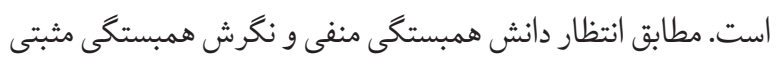
با ميزان مصرف دارد.

در بخش كيفى نيز باهدف كسب بينش عميق تر نسبت به موانع كاهش دي دئ

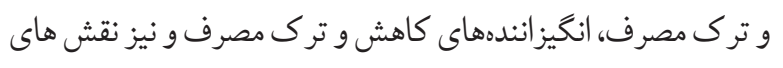
دو ساختار اجتماعى مهم و موثر در شكل گيرى و استمرار الكوى تغذيه نوجو انان يعنى مدرسه و خانواده، تحليل محتواى كيفى انجام شد. يافته

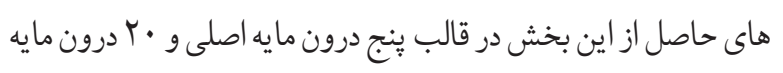

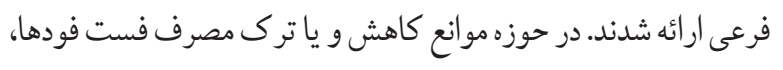
مشاركت كنند انان بر جهار عامل ويزكى هاى محيطى شامل؛ تعدد مر اكز

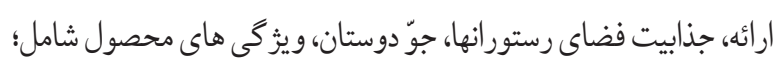

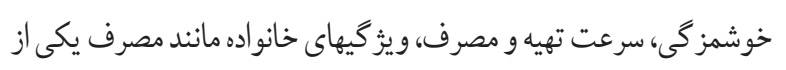

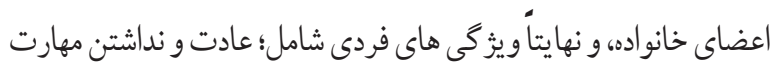

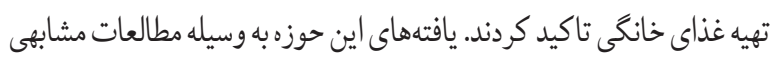

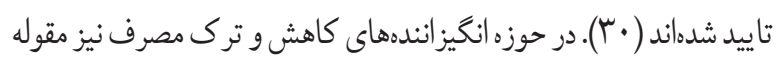

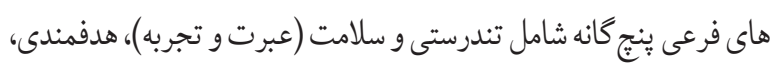
جايكز ين مورد علاقه، زيبايى و تناسب اندام، الخوى مناسب و پاداش و تنبيه بودهاند. در بازاريابى اجتماعى پايين دستى (Down-Stream)، عموماً تكيه بر مواردى است كه به طور مستقيم بر مخاطب نهايى اثر كذار هستند.

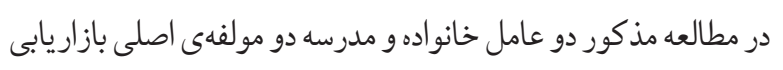
اجتماعى يا يين دستى محسوب مىشوند. در تعيين نقش خانواده، به عنوان
است. لذا برخلاف توصيه مطالعه آنها، اين مطالعه نقطه تمر كز براى

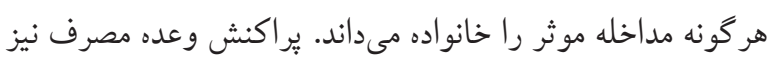

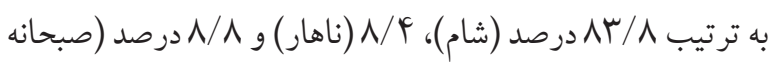

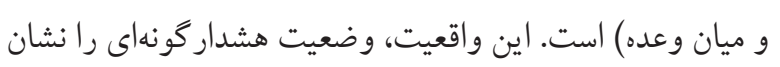

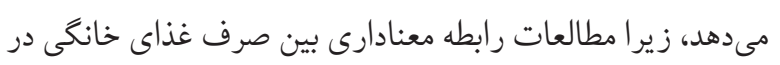

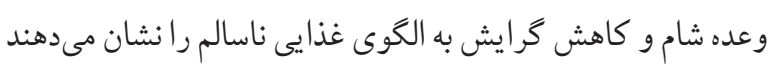

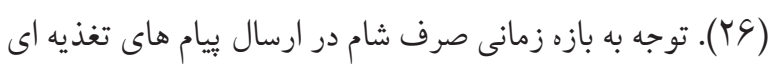
و يا پخش آكهى هاى سلامت در رسانه هاى جمعى مانند راديو و باز زمانى

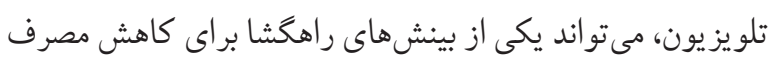

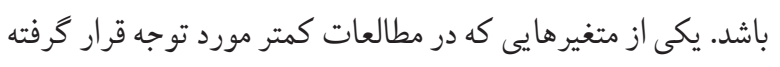

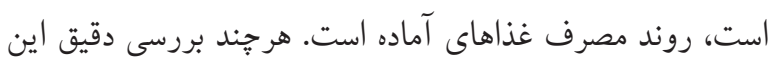

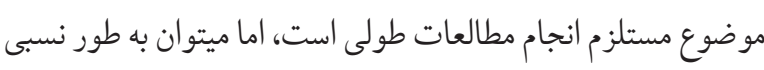

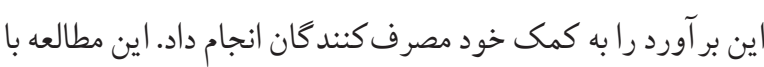
يرسش از دانش آموزان درباره روند مصرفشان در بازه زمانى 9 ماهد

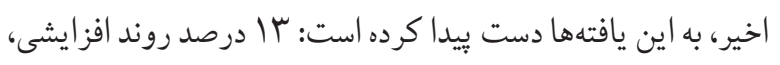

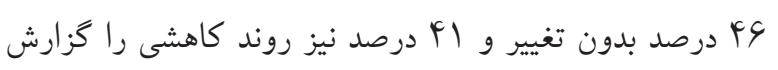

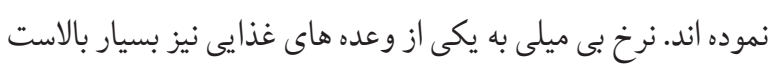

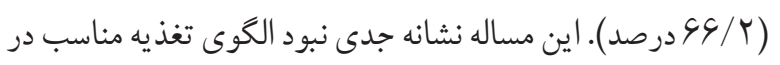
بين دانش آموزان است. در اين بين، بىميلى نسبت به وعده صبحانه شيوع بالاترى دارد ( ب ب ب درصد).

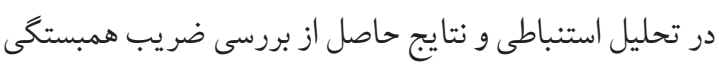

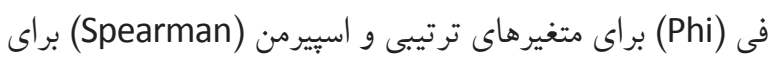

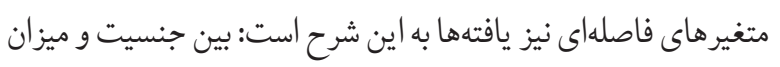

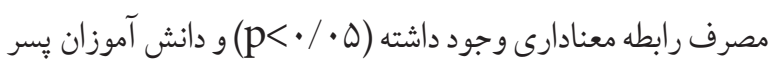
بيش از دختران فست فود مصرف مى كنند. اين يافته با برخى مطالعات

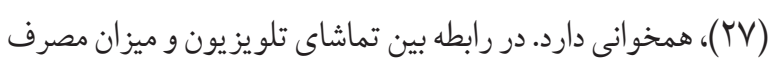

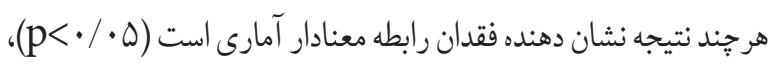

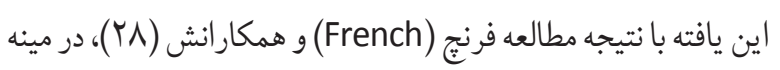

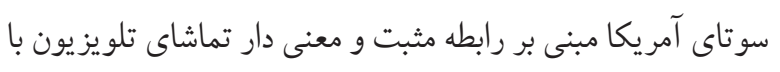

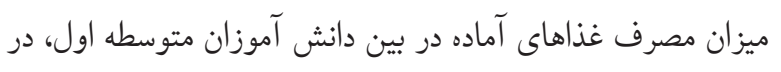

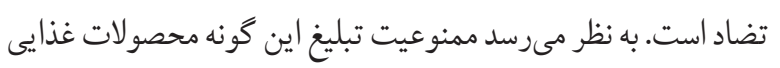


بر آكاهى از وضعيت شاخصهاى مرتبط با مصرف غذاهاى آماده در

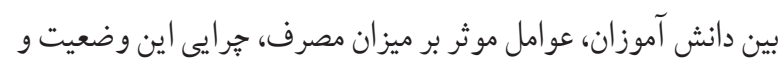

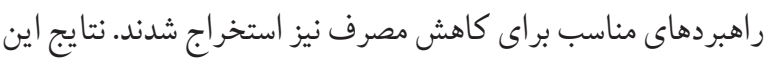

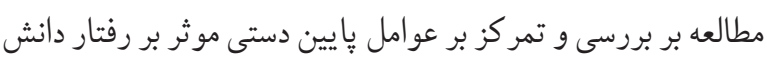

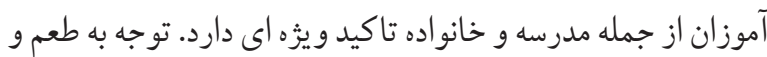

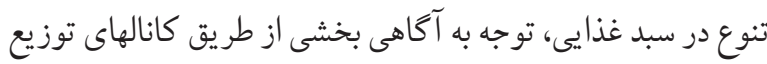

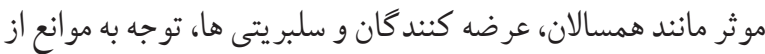

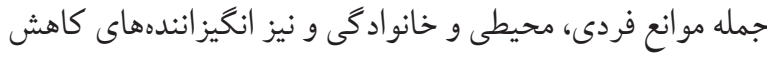

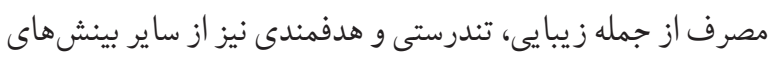

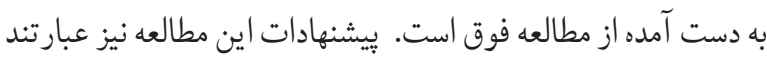
از: طر احى مداخلات بازاريابى اجتماعى به كمك يافته هاى اين مطالعه

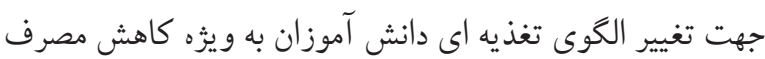

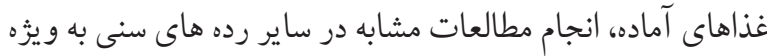
در دوران مقطع متوسطه دوم به عنوان دوره حياتى مكمل در شكل

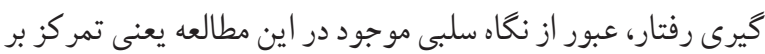
كاهش مصرف غذاهاى ناسالم و توجه به كسب بينش جهت ترويج الخوهاى غذايى سالم ماندن ميوهها و سبز يجات، و در نهايت توصيه

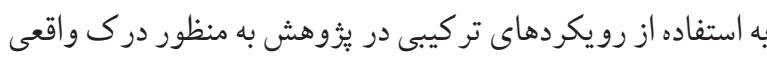

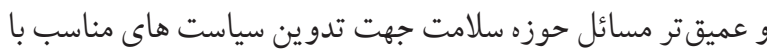
هدف ارتقاى سلامت فرد و جامعه. تضاد منافع

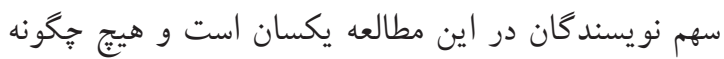
تضاد منافعى وجود ندارد. تشكر و قدردانى تصني نو يسند كان بر خود لازم مى دانند مراتب سياس و قدر دانى خود

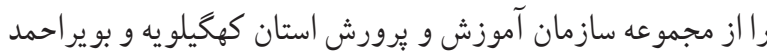
از جمله؛ معاونت يُزوهشى، كاركروه يُزوهشى، حراست، كارشناس

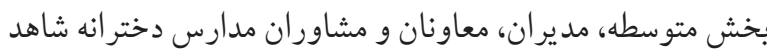

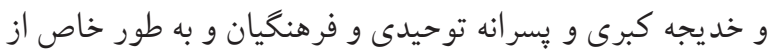
دانش آموزان مدارس فوق ابراز نمايند.
يكى از مهمتر ين عو امل مرتبط با الخوهاى رفتارى فرزندان، جهار عامل آكاه سازى (تجربه و عبرت)، مديريت غذايى (تهيه غذاي مورد علاقه، تنوع غذايى)، مديريت يول تو جيبى و اهرم ياداش و تنبيه از بين اظهار

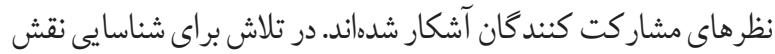
يكى ديخر از اين ساختارهاى موثر، يعنى مدرسه، نيز عوامل جهار كانه آكاهى

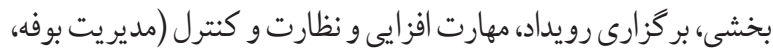
ياداش و تنبيه) از بحثهاى گروهى متمر كز استخراج شدهاند. در آخرين

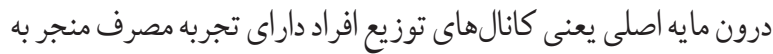

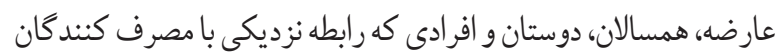

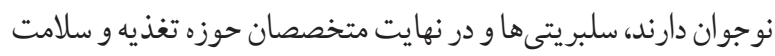
ييام رسانهاى موثر براى مداخلات اين حوزه معرفى شدند. تحليل دادههاى

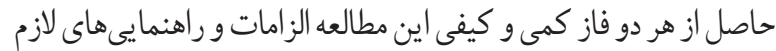
براى طراحى و وياده سازى مداخلات بازاريابى اجتماعى جهت كاهش ون مصرف غذاهاى آماده را فراهم مىسازد.

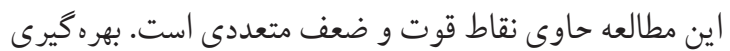

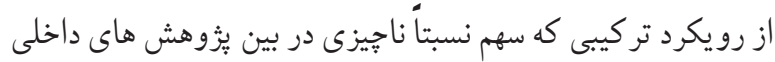

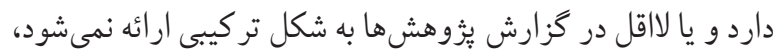
هدف گذارى قشر نوجوان به عنوان اصلىترين گروه جهت اصلاح و تقويت الكوهاى رفتارى به ويزه الكوى تغذيه و نيز استفاده از رويكرد كيفى در مواجهه با مخاطبان نوجوان باوجود دشوارىهاى

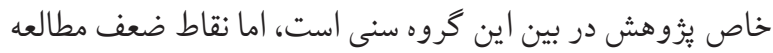

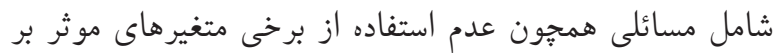

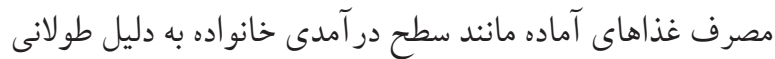

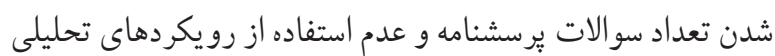
نزديكتر به ماهيت روش تركيبى از نقاط ضعف اصلى و دو مساله دشوارى هماهنكى براى دسترسى به مخاطبان هدف و مطالعات

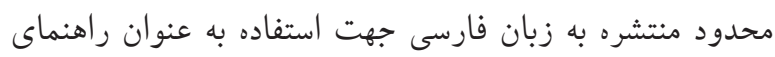
يثزوهش نيز از محدوديت هاى مطالعه بودهاند. نتيجه كيرى نيز نيز با انجام يُزوهش سازنده با رويكرد تر كيبى مى توان به بينشهاى

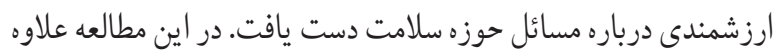




\section{References}

1. Baudrillard J. La societe de consommation : ses mythes, ses structures. 2 ed. Tehran: Sales; 2010.

2. Grumett D, Bretherton L, Holmes SR. Fast food: A critical theological perspective. Food, Culture \& Society. 2011;14(3):375-92. https://doi.org/10.2752/175174411X12961586033609

3. Kessler DA. The end of overeating: Taking control of the insatiable American appetite: Rodale; 2010.

4. Bahadoran Z, Mirmiran P, Azizi F. Fast food pattern and cardiometabolic disorders: a review of current studies. Health promotion perspectives. 2015;5(4):231. https://doi.org/10.15171/hpp.2015.028 PMid:26933642 PMCid:PMC4772793

5. Labensky S. Webster's new world dictionary of culinary arts: EC LINK LTD.; 2005.

6. Dingman DA, Schulz MR, Wyrick DL, Bibeau DL, Gupta SN. Factors related to the number of fast food meals obtained by college meal plan students. Journal of American College Health. 2014;62(8):562-9. https://doi.org/10.1080/07448481.2014.945456 PMid:25057766

7. Mendonça RdD, Pimenta AM, Gea A, de la Fuente-Arrillaga C, Martinez-Gonzalez MA, Lopes ACS, et al. Ultraprocessed food consumption and risk of overweight and obesity: the University of Navarra Follow-Up (SUN) cohort study. The American journal of clinical nutrition. 2016;104(5):1433-40. https://doi.org/10.3945/ajcn.116.135004 PMid:27733404

8. Polsky JY, Moineddin R, Glazier RH, Dunn JR, Booth GL. Relative and absolute availability of fast-food restaurants in relation to the development of diabetes: A population-based cohort study. Canadian Journal of Public Health. 2016;107(1):eS27-eS33. https://doi.org/10.17269/CJPH.107.5312 PMid:27281517

9.UngerJB, ReynoldsK,ShakibS,Spruijt-MetzD,SunP,JohnsonCA. Acculturation, physical activity, and fast-food consumption among Asian-American and Hispanic adolescents. Journal of community health. 2004;29(6):467-81. https://doi.org/10.1007/s10900-004-3395-3 PMid:15587346

10. Reiner RC, Olsen HE, Ikeda CT, Echko MM, Ballestreros KE, Manguerra $\mathrm{H}$, et al. Diseases, injuries, and risk factors in child and adolescent health, 1990 to 2017: findings from the Global Burden of Diseases, Injuries, and Risk Factors 2017 Study. JAMA pediatrics. 2019:e190337-e.

11. Hodhodinezhad N, Ashrafi-rizi H, Shahrzadi L, Soleymani M. Effect of Using Social Marketing Techniques on the Knowledge and Attitudes of Students and Faculty Members of Isfahan University of Medical Sciences to the Medical Librarianship Services. Journal of Health Administration. 2016;19(65):31-42.

12. Kotler PT, Lee NR. Up and out of poverty: The social marketing solution: Pearson Prentice Hall; 2009.

13. Kubacki K, Rundle-Thiele S, Pang B, Buyucek N. Minimizing alcohol harm: A systematic social marketing review (20002014). Journal of Business Research. 2015;68(10):2214-22. https://doi.org/10.1016/j.jbusres.2015.03.023

14. Collins K, Tapp A, Pressley A. Social marketing and social influences: Using social ecology as a theoretical framework. Journal of Marketing Management. 2010;26(13-14):1181-200. https://doi.org/10.1080/0267257X.2010.522529

15. Kubacki K, Rundle-Thiele S. Expanding the formative research toolkit. Formative Research in Social Marketing: Springer; 2017. p. 1-9. https://doi.org/10.1007/978-981-10-1829-9_1

16. Mohammadpour A. Meta Method: The Philosophical and Practical Foundations. Tehran: Jameshenasan; 2010. 51-5 p.

17. Roberto EL, Kotler P. Social Marketing: Strategies for Changing Public Behavior. New York: The Free Press and Gerald Zaltman (1971)," Social Marketing: An Ap-proach to PlannedSocialChange,"JournalofMarketing.1989;35:3-12. https://doi.org/10.1177/002224297103500302 PMid:12276120

18. Basil M. Survey for formative research. Formative research in social marketing: Springer; 2017. p. 251-63. https://doi.org/10.1007/978-981-10-1829-9_12

19. Dolnicar S, Grün B, Leisch F, Schmidt K. Required sample sizes for data-driven market segmentation analyses in tourism. Journal of Travel Research. 2014;53(3):296-306. https://doi.org/10.1177/0047287513496475

20. Dolnicar S, Grün B, Leisch F. Increasing sample size compensates for data problems in segmentation studies. Journal of Business Research. 2016;69(2):992-9. https://doi.org/10.1016/j.jbusres.2015.09.004

21. Weinreich NK. Hands-on social marketing: a step-by-step guide to designing change for good: Sage Publications; 2010.

22.JohnstoneM-L.Depthinterviewsandfocusgroups. Formative Research in Social Marketing: Springer; 2017. p. 67-87. https://doi.org/10.1007/978-981-10-1829-9_5

23. Mayring P. Qualitative content analysis. A companion to qualitative research: Sage; 2004. p. 159-76.

24. Neumark-Sztainer D, Story M, Perry C, Casey MA. Factors influencing food choices of adolescents: findings from focus-group discussions with adolescents. Journal of the American dietetic association. 1999;99(8):929-37. https://doi.org/10.1016/S0002-8223(99)00222-9 
25. Seo H-s, Lee S-K, Nam S. Factors influencing fast food consumption behaviors of middle-school students in Seoul: an application of theory of planned behaviors. Nutrition research and practice. 2011;5(2):169-78. https://doi.org/10.4162/nrp.2011.5.2.169 PMid:21556232 PMCid:PMC3085807

26. Stockmyer C. Remember when mom wanted you home for dinner? Nutrition Reviews. 2001;59(2):57-60. https://doi.org/10.1111/j.1753-4887.2001.tb06978.x PMid:11310778

27. Bauer KW, Larson NI, Nelson MC, Story M, NeumarkSztainer D. Fast food intake among adolescents: secular and longitudinal trends from 1999 to 2004. Preventive medicine. 2009;48(3):284-7. https://doi.org/10.1016/j.ypmed.2008.12.021 PMid:19166872

28. French SA, Story M, Neumark-Sztainer D, Fulkerson
JA, Hannan P. Fast food restaurant use among adolescents: associations with nutrient intake, food choices and behavioral and psychosocial variables. International journal of obesity. 2001;25(12):1823. https://doi.org/10.1038/sj.ijo.0801820 PMid:11781764

29. Moreno LA, Rodriguez G, Fleta J, Bueno-Lozano M, Lazaro A, Bueno $G$. Trends of dietary habits in adolescents. Critical reviews in food science and nutrition. 2010;50(2):106-12. https://doi.org/10.1080/10408390903467480 PMid:20112152

30. Boutelle KN, Fulkerson JA, Neumark-Sztainer D, Story M, French SA. Fast food for family meals: relationships with parent and adolescent food intake, home food availability andweightstatus. Publichealthnutrition.2007;10(1):16-23. https://doi.org/10.1017/S136898000721794X PMid:17212838 